\title{
Pyrrolo[2,1-f][1,2,4]triazine: a promising fused heterocycle to target kinases in cancer therapy
}

\author{
Sarbjit Singh $\mathbb{1}^{1} \cdot$ Divya Utreja $^{2} \cdot$ Vimal Kumar ${ }^{3}$
}

Received: 17 July 2021 / Accepted: 29 October 2021 / Published online: 13 November 2021

(C) The Author(s), under exclusive licence to Springer Science+Business Media, LLC, part of Springer Nature 2021

\begin{abstract}
Cancer is the second leading cause of death worldwide responsible for about 10 million deaths per year. To date several approaches have been developed to treat this deadly disease including surgery, chemotherapy, radiation therapy, hormonal therapy, targeted therapy, and synthetic lethality. The targeted therapy refers to targeting only specific proteins or enzymes that are dysregulated in cancer rather than killing all rapidly dividing cells, has gained much attention in the recent past. Kinase inhibition is one of the most successful approaches in targeted therapy. As of 30 March 2021, FDA has approved 65 small molecule protein kinase inhibitors and most of them are for cancer therapy. Interestingly, several kinase inhibitors contain one or more fused heterocycles as part of their structures. Pyrrolo[2,1-f][1,2,4]triazine is one the most interesting fused heterocycle that is an integral part of several kinase inhibitors and nucleoside drugs viz. avapritinib and remdesivir. This review articles focus on the recent advances made in the development of kinase inhibitors containing pyrrolo[2,1-f] $[1,2,4]$ triazine scaffold.
\end{abstract}

\section{Graphical Abstract}

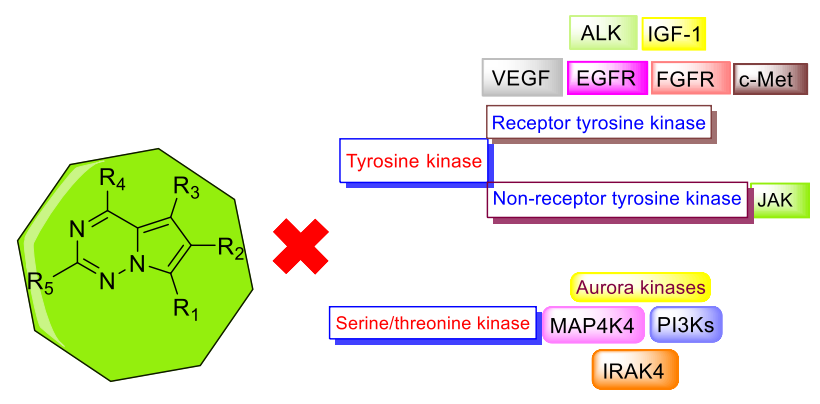

Keywords Pyrrolo[2,1-f][1,2,4]triazine $\cdot$ Kinase inhibition $\cdot$ Fused heterocycles $\cdot$ Cancer $\cdot$ Targeted therapy

\section{Introduction}

Cancer is the second leading cause of death worldwide responsible for about 10 million deaths per year [1]. On average, one in six deaths is due to cancer. To date, several approaches have been developed to treat this deadly disease viz. surgery [2], chemotherapy [3-6], radiation therapy [7], hormonal therapy [8,9], targeted
Sarbjit Singh

sarbjit.singh@unmc.edu

$\triangle$ Divya Utreja utrejadivya@pau.edu

$\triangle$ Vimal Kumar

bhardwajvk@nitj.ac.in
1 Eppley Institute for Research in Cancer and Allied Diseases, University of Nebraska Medical Center, Omaha, NE 68198, USA

2 Department of Chemistry, Punjab Agricultural University, Ludhiana 141004 Punjab, India

3 Department of Chemistry, Dr B. R. Ambedkar National Institute of Technology (NIT), Jalandhar 144011 Punjab, India 
therapy [10-13], and synthetic lethality [14]. The choice of treatment depends upon the type, location, and stage of cancer. The use of surgery, hormone therapy, chemotherapy, and radiation therapy are being in use since the 19th century whereas immunotherapy and targeted therapies were developed in the 20th century. If detected early, surgery is the best choice of treatment; however, in most cases cancer is metastasized to other parts of the body prior to detection so requires combination of other therapies prior or after surgery. Radiation therapy involves the use of ionizing radiations (X-ray) to kill cancer cells and shrink tumors. Radiation therapy is not preferred if cancer is diagnosed in late stages or if the tumor is located on vulnerable places. Chemotherapy involves the use of single or combination of cytotoxic drugs which affect rapidly dividing cells. The major drawback of chemotherapy is its specificity, the cytotoxic drugs also kill healthy cells especially those which are fast growing e.g., cells on intestinal lining. Several combinations of cytotoxic drugs have been developed to treat various forms of cancers e.g., combination of cyclophosphamide, methotrexate, 5-fluorouracil, vinorelbine is given to patients with breast cancer [15], the combination of Doxorubicin, bleomycin, vinblastine, dacarbazine is optimized for Hodgkin's lymphoma [16]. Immunotherapy refers to use of therapeutic strategies that involve the use of patient's own immune system to fight cancer. Examples include the use of interferons and other cytokines $[17,18]$ to induce an immune response in patients with renal cell carcinoma and melanoma $[19,20]$. Hormonal therapy refers to the blocking or administration of certain hormones to treat cancer. For example, the blocking of estrogen or testosterone is beneficial in some patients suffering from breast or prostate cancers $[21,22]$. However, in most cases the patients develop resistance to hormone therapy demanding the use of next-generation drugs [23]. Synthetic lethality is an approach used to cure those cancers in which a combination of deficiencies in the expression of two or more genes leads to cell death but one of these genes does not. Examples include the use of PARP inhibitors Olaparib, Rucaparib, Niraparib for ovarian cancer patients with mutated BRCA1 [24, 25].

Targeted therapy refers to the use of those drugs that target only specific proteins or enzymes that are dysregulated in cancer rather than killing all rapidly dividing cells [10, 26, 27]. Various small organic molecules and monoclonal antibodies are in clinical use that targets such enzymes or proteins. Examples include the use of tyrosine kinase inhibitors imatinib (for chronic myelogenous leukemia and acute lymphocytic leukemia) and gefitinib (for certain breast and lung cancers) [28, 29]. Rituximab is a monoclonal antibody used to treat
non-Hodgkin lymphoma, chronic lymphocytic leukemia, and certain autoimmune diseases [30-32]. Although all approaches are used to treat various forms of cancer, the use of targeted therapy is an active and most advanced area of cancer research these days.

Kinases are the enzymes that catalyze the transfer of phosphate groups from high-energy, phosphate-donating molecules to specific substrates viz. proteins, lipids, and carbohydrates through a process known as phosphorylation [33-36]. Kinases have been classified into different categories depending upon the substrate they phosphorylate. Protein kinases are kinases that phosphorylate amino acids residues of proteins either on serine/threonine and/or tyrosine or histidine residues. Approximately $30 \%$ of the current $\mathrm{R} \& \mathrm{D}$ budget in pharmaceutical companies is focused on developing kinase inhibitors to treat cancer, inflammatory disorders, and other diseases. After the approval of Imatinib, a tyrosine kinase inhibitor, in 2001, FDA has approved 65 small molecule protein kinase inhibitors as of 30 March 2021 [37].

Fused heterocycles are the organic compounds in which two heterocycles are fused and the $\pi$-electrons move on both heterocyclic rings by resonance thus providing a unique set of electrons donors and acceptors. Fused heterocycles are of high interest in designing drugs targeting kinases due to their ability to provide selectivity for a specific kinase or its isoform [38-41]. The presence of multiple heteroatoms at specific positions on fused heterocycles allows them to form hydrogen bonds and other interactions with surrounding amino acid residues that are sometimes not possible with monocyclic heterocycles [42] or heterocycles fused with phenyl rings [43]. Most of the FDA-approved kinases inhibitors contain one or more heterocyclic rings and 29 among them (Table 1) possess fused heterocycles with two or more nitrogen atoms. Pyrrolo[2,1-f][1,2,4]triazine is one of the most interesting fused heterocycles that is an integral part of several kinase inhibitors and nucleoside drugs [44]. It is an integral part of avapritinib recently approved for adults with unresectable or metastatic gastrointestinal stromal tumor harboring a plateletderived growth factor receptor alpha exon 18 mutation, including D842V mutations [45]. Pyrrolo[2,1-f][1,2,4] triazine is also a part of nucleoside [46, 47] drug remdesivir used to treat broad-spectrum viral infections including SARS COVID-19 [48]. Various synthetic strategies have been developed to synthesize pyrrolo $[2,1-f][1,2,4]$ triazine either starting from triazine or pyrrole [48]. Scheme 1 depicts the general methods of synthesis of pyrrolo[2,1-f] $[1,2,4]$ triazine. The focus of this review is to cover the recent advances made in the development of various kinase inhibitors possessing pyrrolo[2,1-f][1,2,4]triazine scaffold. 
Table 1 List of FDA-approved kinase inhibitors with fused heterocyclic rings

\begin{tabular}{|c|c|c|c|c|}
\hline Name & Structure & Target & Fused heterocycle & References \\
\hline Abemaciclib & & $\mathrm{CDK} 4 / 6$ & benzimidazole & {$[157]$} \\
\hline Acalabrutinib & & Bruton tyrosine kinase & $\begin{array}{l}\text { dihydroimidazo[1,5-a] } \\
\text { pyrazine }\end{array}$ & [158] \\
\hline Afatinib & & EGFR, ErbB2, ErbB4 & quinazoline & [159] \\
\hline Avapritinib & & GIST with PDGFR exon 18 mutations & $\begin{array}{l}\text { pyrrolo[2,1-f][1,2,4] } \\
\text { triazine }\end{array}$ & [45] \\
\hline Axitinib & & VEGFR1/2/3, PDGFR $\beta$ & indazole & {$[160]$} \\
\hline Baricitinib & & JAK1/2 & pyrrolo[2,3-d]pyrimidine & {$[161]$} \\
\hline Benimetinib & & MEK1/2 & benzimidazole & [162] \\
\hline
\end{tabular}


Table 1 (continued)

\begin{tabular}{|c|c|c|c|c|}
\hline Name & Structure & Target & Fused heterocycle & References \\
\hline Capmatinib & & MET & $\begin{array}{l}\text { imidazo }[1,2-\mathrm{b}][1,2,4] \\
\text { triazine }\end{array}$ & [86] \\
\hline Dacomitinib & & FR/ErbB2/ErbB4 & quinazoline & {$[163]$} \\
\hline Erdafitinib & & FGFR1/2/3/4 & quinoxaline & {$[164]$} \\
\hline Erlotinib & & EGFR & quinazoline & {$[165]$} \\
\hline Gefitinib & & EGFR & quinazoline & {$[163]$} \\
\hline Ibrutinib & & Bruton tyrosine kinase & pyrazolo[5,4-d]pyrimidine & [166] \\
\hline Lapatinib & & EGFR, ErbB2 & quinazoline & {$[167]$} \\
\hline Larotrectinib & & NTRK & pyrazolo[1,5-a]pyrimidine & [168] \\
\hline
\end{tabular}


Table 1 (continued)

\begin{tabular}{llll}
\hline Name & Structure & Target & Fused heterocycle \\
\hline Palbociclib & CDK4/6 & pyrido[2,3-d]pyrimidin-7- & one \\
[169]
\end{tabular}

Pazopanib<smiles>Cc1ccc(Nc2nccc(N(C)c3ccc4c(C)n(C)nc4c3)n2)cc1S(N)(=O)=O</smiles>

Pemigatinib<smiles>CCN1C(=O)N(c2c(F)c(OC)cc(OC)c2F)Cc2cnc3[nH]c(CN4CCOCC4)cc3c21</smiles>

Pexidartinib<smiles>FC(F)(F)c1ccc(CNc2ccc(Cc3c[nH]c4ncc(Cl)cc34)cn2)cn1</smiles>

Ponatinib<smiles>Cc1ccc(C(=O)Nc2ccc3c(c2)CN2CCN(C)CC32C)cc1C#Cc1cnc2cccnn12</smiles>

Ribociclib<smiles>CN(C)C(=O)c1cc2cnc(Nc3ccc(N4CCNCC4)cn3)nc2n1C1CCCC1</smiles>

VEGFR1/2/3, PDGFR $\alpha / \beta$, FGFR1/3, Kit, indazole Lck, Fms, Itk

pyrrolo[2,3-b]pyridine

CSFR1/Kit

pyrrolo[2,3-b]pyridine

BCR-Abl, BCR-Abl T315I, VEGFR,

Imidazo[1,2-b]pyridazine PDGFR, FGFR, EphR, Src family kinases, Kit, RET, Tie2, Flt

CDK4/6

pyrrolo[2,3-d]pyrimidine

[169] 
Table 1 (continued)

\begin{tabular}{|c|c|c|c|c|}
\hline Name & Structure & Target & Fused heterocycle & References \\
\hline Ruxolitinib & & JAK1/2 & pyrrolo[2,3-d]pyrimidine & {$[174]$} \\
\hline Selpercatinib & & RET & pyrazolo[1,5-a]pyridine & {$[175]$} \\
\hline Selumetinib & & MEK1/2 & benzo[d]imidazole & {$[176]$} \\
\hline Tofacitinib & & JAK1/3 & pyrrolo[2,3-d]pyrimidine & {$[177]$} \\
\hline Trilaciclib & & CDK4/6 & pyrrolo[2,3-d]pyrimidine & {$[178]$} \\
\hline Tucatinib & & ErbB2/HER2 & $\begin{array}{l}\text { quinazoline and }[1,2,4] \\
\text { triazolo[1,5-a]pyridine }\end{array}$ & [179] \\
\hline Vandetanib & & $\begin{array}{l}\text { EGFRs, VEGFRs, RET, Brk, Tie2, EphRs, } \\
\text { Src family kinases }\end{array}$ & quinazoline & {$[180]$} \\
\hline Vemurafenib & & $\begin{array}{l}\text { A/B/C-Raf, B-Raf (V600E), SRMS, ACK1, } \\
\text { MAP4K5, FGR }\end{array}$ & pyrrolo[2,3-b]pyridine & {$[181]$} \\
\hline
\end{tabular}


Starting from Triazines
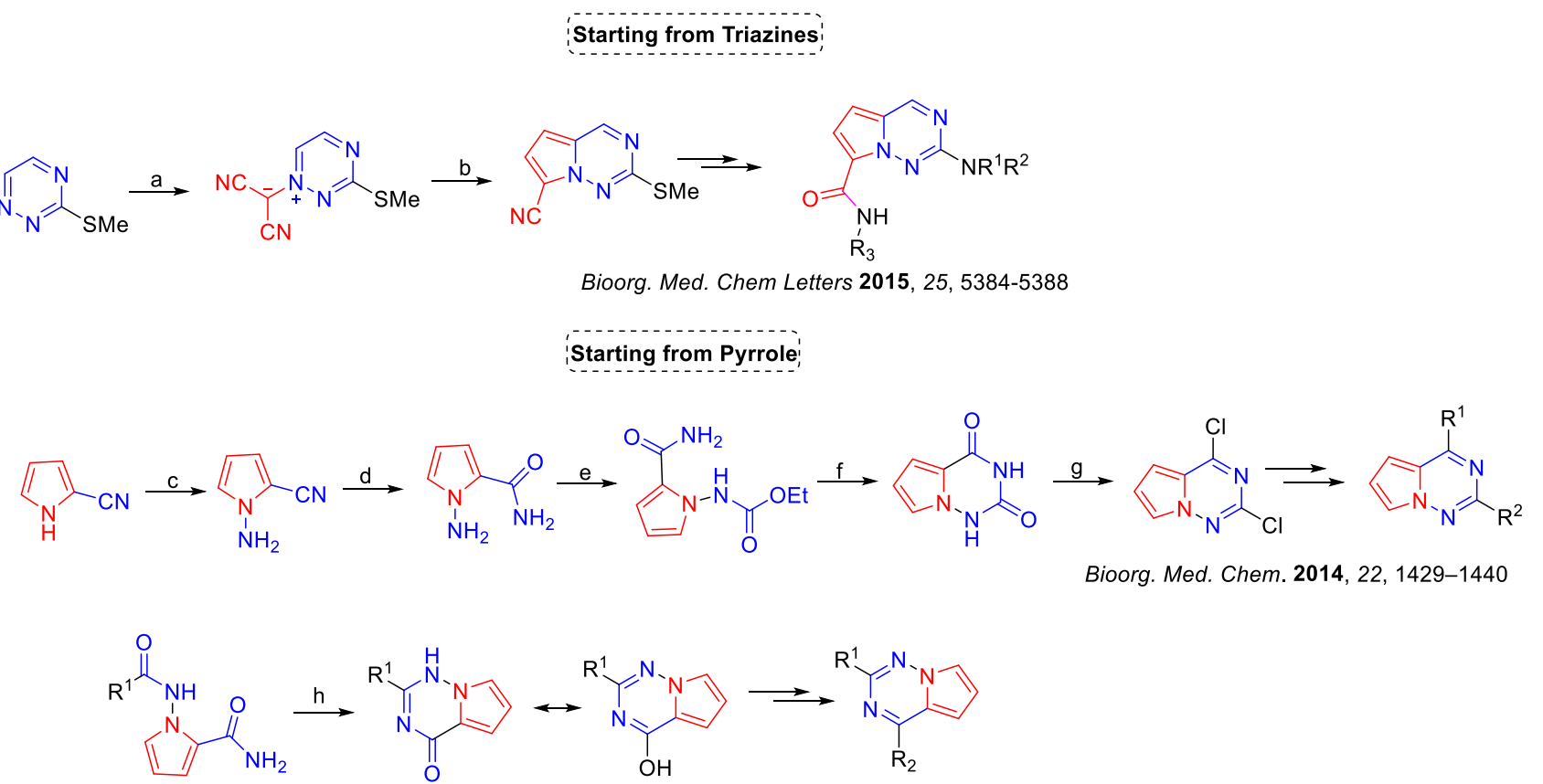

ACS Medicinal Chemistry Letters 2015, 6, 254-259;

Synthesis 2016, 48, 1226-1234.
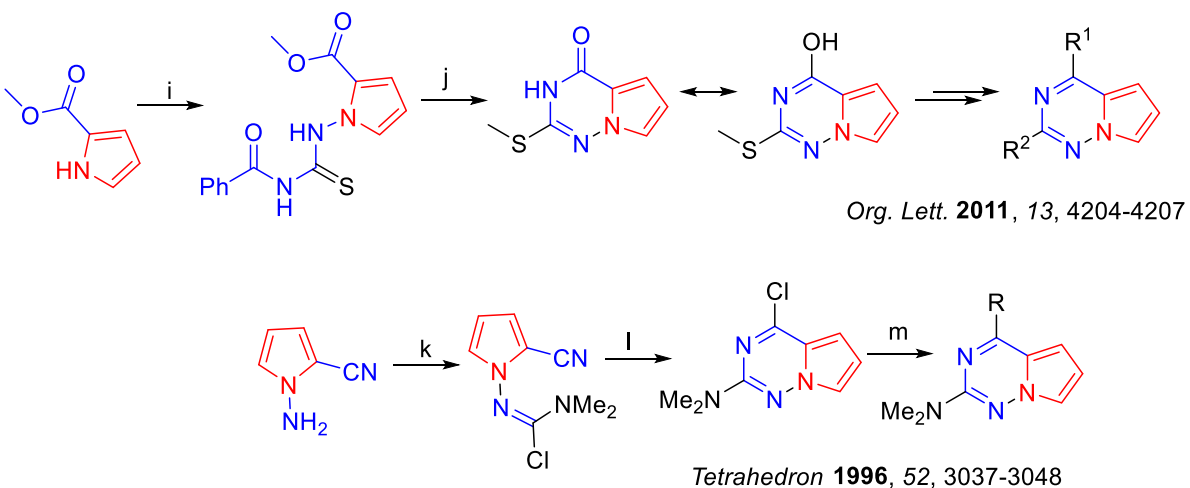

Scheme 1 Reagents and conditions: a Tetracyanoethylene oxide, THF; b Phenyl vinyl sulfoxide, 1,4-dioxane, Reflux; c NaH, DMF, $\mathrm{NH}_{2} \mathrm{Cl}$, rt; d KOH, $\mathrm{H}_{2} \mathrm{O}$, rt; e pyridine, $\mathrm{ClCO}_{2} \mathrm{Et}$, dioxane, $110^{\circ} \mathrm{C}$; f EtOH, EtONa, reflux; $\mathbf{g} \mathrm{POCl}_{3}$, DIPEA, $120^{\circ} \mathrm{C} ; \mathbf{h ~ N H}{ }_{3}, \mathrm{H}_{2} \mathrm{O}, 80^{\circ} \mathrm{C} ; \mathbf{i}$

\section{Tyrosine kinase inhibitors}

\section{Receptor tyrosine kinase inhibitors}

Tyrosine kinase inhibitors (TKI) are the largest class of kinase inhibitors. 48 among 62 FDA-approved kinases inhibitors target tyrosine kinases [49, 50]. 13 among 48 are non-receptor tyrosine kinase inhibitors whereas 35 target receptor protein tyrosine kinases [37]. In 2020 FDA approved 10 TKI viz. Tepotinib, Capmatinib, Pemigatinib, Ripertinib, Avapritinib, Tucatinib, Selumetinib, Pralsetinib, and Seppercatinib [51]. The epidermal growth factor receptor (EGFR, ErbB-1, HER1) is a transmembrane tyrosine kinase receptor that belongs to the ERBB family of proteins [52]. EGFR regulates several cell signaling
(1) Chloramine, KO-t-Bu, THF, $10^{\circ} \mathrm{C}$; (2) Benzoyl isothiocyanate, THF; j (1) $2 \mathrm{M} \mathrm{NaOH}, \mathrm{H}_{2} \mathrm{O}, 85^{\circ} \mathrm{C}$, (2) MeI, THF, $45^{\circ} \mathrm{C}$; $\mathbf{k}$ $\mathrm{CCl}_{2} \mathrm{NMe}_{2} \mathrm{Cl}, \mathrm{ClCH}_{2} \mathrm{CH}_{2} \mathrm{Cl}$, Reflux; l $\mathrm{HCl} ; \mathbf{m} \mathrm{POCl}_{3}, \mathrm{PCl}_{5}, 110^{\circ} \mathrm{C}$ [143, 151-156]

pathways, proliferation, differentiation, and division. EGFR family consists of four closely related proteins EGFR (HER1/ErbB1), ErbB2 (HER2/neu), ErbB3 (HER3), and ErbB4 (HER4) [53]. The activation and autophosphorylation of the intracellular tyrosine kinase domain of receptors trigger several signaling pathways such as PI3K/AKT/mTOR, RAS/RAF/MEK, and STAT. Overexpression of EGFR results in the development of various cancers. Blocking of EGFR signaling has developed as a promising therapeutic strategy to prevent the growth of EGFR-expressing tumors. Several small organic molecules developed as EGFR TKIs are either in clinical use or clinical/preclinical trials [54]. Gefitinib and erlotinib are the first-generation EGFR inhibitors approved for the treatment of NSCLC patients in 2003 and 2004, respectively [55, 56]. 


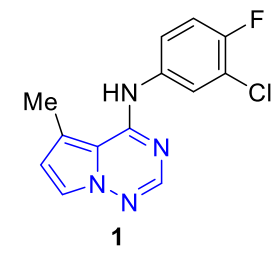

VEGFR-2 $\left(\mathrm{IC}_{50}>10 \mu \mathrm{M}\right)$ $\operatorname{EGFR}\left(\mathrm{IC}_{50}=0.100 \mu \mathrm{M}\right)$<smiles>Cc1ccc(Nc2ncnn3cc(C)c(C)c23)cc1O</smiles>

3

VEGFR-2 $\left(\mathrm{IC}_{50}=0.023 \mu \mathrm{M}\right)$

$\operatorname{EGFR}\left(\mathrm{IC}_{50}=0.200 \mu \mathrm{M}\right)$

Fig. 1 Structures of compounds 1-3

VEGF are receptors for vascular endothelial growth factors (VEGF). These are of three main types, VEGF1, VEGF2, and VEGF3 [57, 58]. Overexpression of VEGF receptors is linked to soft tissue sarcomas, renal cell carcinomas, colorectal cancers, thyroid cancer, and several other cancers. Axitinib (VEGF1 inhibitor) [59], Cabozantinib (VEGF2 inhibitor) [60], Lenvatinib (VEGFR inhibitor) [61], Pazopanib (VEGFR1/2/3 inhibitor) [62], Regorafenib (VEGFR1/2/3 inhibitor) [63], Sorafenib (VEGFR1/2/3 inhibitor) [64], Sunitinib (VEGF2 inhibitor) [65], and Vandetanib (VEGF2 inhibitor) [66] are in clinical use for the treatment of various cancers [67].

Hunt et al. synthesized a series of compounds possessing pyrrolo[2,1-f][1,2,4]triazine nucleus and evaluated their activity on VEGFR-2 and EGFRkinases [68]. Compounds 2 $\left(\mathrm{IC}_{50}=0.066 \mu \mathrm{M}\right)$ and $\mathbf{3}\left(\mathrm{IC}_{50}=0.023 \mu \mathrm{M}\right)$ displayed most potent activities against VEGFR-2, whereas compound $\mathbf{1}$ $\left(\mathrm{IC}_{50}=0.100 \mu \mathrm{M}\right)$ was more selective for EFGR (Fig. 1). Compounds were also tested for their activities on DiFi cell lines (cells sensitive to EGFR inhibitors) and human umbilical vein endothelial cells (HUVECs). However, the cellular behaviors of these compounds were somewhat inconsistent.

The same group also synthesized another series of pyrrolotriazine derivatives as VEGFR-2 inhibitors [69]. Compounds 4 and 5 (Fig. 2) displayed the most potent cellular activity and VEGFR-2 inhibition. Low rates of glucuronidation (an indication of higher metabolic stability) were observed with both compounds.

The fibroblast growth factor receptors (FGFR) are the family of tyrosine receptor kinases that bind to members of the fibroblast growth factor (FGF) family of proteins and regulate the fundamental process of cell development [70]. These are of four main types, FGFR 1, FGFR2, FGFR3, and FGFR4. FGFR5 (also known as FGFRL1) is a closely related receptor that can bind FGFs but has no tyrosine kinase domain. FGFRs are over-expressed in several cancers [71]. Erdafitinib (FGFR1/2/3/4 inhibitor), Nintedanib (FGFR $1 / 2 / 3$ ) are the only two FGFR inhibitors currently in clinical use for the treatment of Urothelial bladder cancers and Idiopathic pulmonary fibrosis [72-74].

Borzilleri et al. reported some substituted 4-(2,4-difluoro5-(methoxycarbamoyl)phenylamino)pyrrolo[2,1-f][1,2,4]triazines as inhibitors of VEGFR-2 and FGFR-1 [75]. Compounds 6, 7, and 8 displayed the most potent activities among all compounds screened (Fig. 2). Table 2 shows the VEGFR-2, FGFR-1, and cellular activities of compounds 6-8. Docking studies revealed 8 to be an ATP competitive inhibitor of VEGFR-2. Hydrogen-bond interactions between amide-NH of Cys919 and the N1 of the pyrrolo $[2,1-\mathrm{f}][1,2,4]$ triazine ring anchored 8 to the hinge region of the adenine binding pocket (Fig. 2). In kinome profiling, compound $\mathbf{8}$ showed a good selectivity over a panel of kinases including HER-1, HER-2, PDGFR- $\alpha$, IGF-1R, PKCR, and CDK2. Compound 8 also showed well in vitro metabolic stability and PK profile. In the L2987 cells-driven human lung carcinoma xenograft model, 8 showed robust in vivo efficacy at multiple dosing with no observation of morbidity or weight loss.

Fink Lab discovered compound 9 as potent and selective inhibitor of EFGR $\left(\mathrm{IC}_{50}=0.04 \mu \mathrm{M}\right)$ and HER2 $\left(\mathrm{IC}_{50}=\right.$ $0.04 \mu \mathrm{M})$ [76]. It exhibited $\mathrm{IC}_{50}$ values of 0.86 and $0.46 \mu \mathrm{M}$, respectively on BT474 (breast carcinoma) and Sal2 (salivary gland carcinoma) cell lines. Notably, both cell lines overexpress HER-2. In kinome screening, 9 showed up to 200-fold selectivity over FAK, p38, MAPKAP kinase 2, and IGF-1R (Fig. 3).

Mastalerz and co-workers discovered compounds $\mathbf{1 0}$ and 12 as dual inhibitors of EGFR and HER2 [77]. The methyl group on the pyrrole ring was crucial for the activity of $\mathbf{1 0}$ and 12. Replacing the methyl group of $\mathbf{1 0}$ by OMe (compound 11) resulted in deterioration of activity against both kinases. Compound $\mathbf{1 0}$ was slightly more active than $\mathbf{1 2}$ against both kinases (Fig. 4).

In another report, the same group developed compound 13 containing a morpholine side chain on the pyrrole ring of pyrrolotriazine [78]. A significant improvement of activity against EGFR $\left(\mathrm{IC}_{50}=0.061 \mu \mathrm{M}\right)$ and $\mathrm{HER} \quad\left(\mathrm{IC}_{50}=\right.$ $0.055 \mu \mathrm{M}$ ) was observed compared to $\mathbf{1 0}$ and 12 (Fig. 4). Compound $\mathbf{1 3}$ also displayed good selectivity over a panel of kinases. In vitro cellular assay on N87 cells showed a dose-dependent inhibition of HER2 phosphorylation. Compound $\mathbf{1 3}$ showed a significant reduction of tumor in GEO and N87 xenografts mice model when dosed subcutaneously and orally. Docking studies revealed that $\mathbf{1 3}$ occupied ATP binding sites of EGFR whereas pyrrolotriazine N-1 formed hydrogen bonding with Met769 NH in the hinge region whereas benzyl indazole group was deeply 
Fig. 2 A Structures and activities of compounds $4-8 ;$ B Binding of $\mathbf{8}$ in the ATP binding sites of VEGFR-2 kinase (Figure reproduced with the permission of the original publisher)
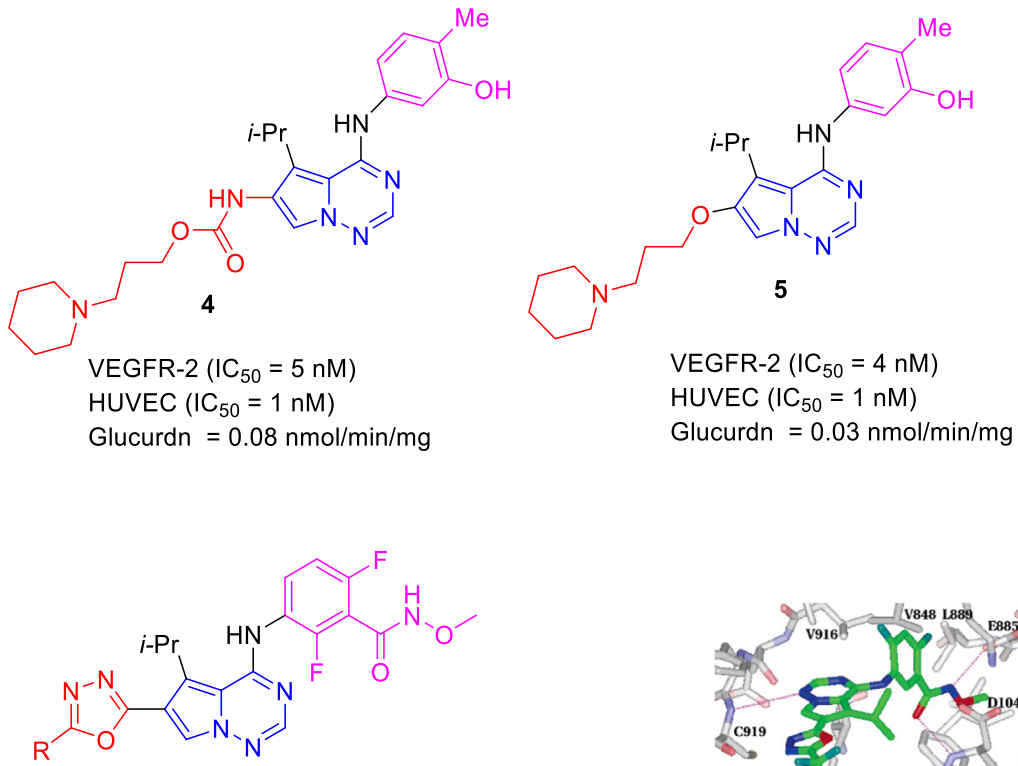

6; $\mathrm{R}=\mathrm{CHF}_{2}\left(\right.$ VEGFR-2 $\left(\mathrm{IC}_{50}=57 \mathrm{nM}\right)$, FGFR-1 $\left(\mathrm{IC}_{50}=100 \mathrm{nM}\right)$

7; $\mathrm{R}=\mathrm{CH}_{2} \mathrm{SO}_{2} \mathrm{CH}_{3}\left(\right.$ VEGFR-2 $\left(\mathrm{IC}_{50}=16 \mathrm{nM}\right)$, FGFR-1 $\left(\mathrm{IC}_{50}=16 \mathrm{nM}\right)$

8; $\mathrm{R}=\mathrm{CF}_{2} \mathrm{SO}_{2} \mathrm{CH}_{3}\left(\right.$ VEGFR-2 $\left(\mathrm{IC}_{50}=53 \mathrm{nM}\right)$, FGFR-1 $\left(\mathrm{IC}_{50}=220 \mathrm{nM}\right)$

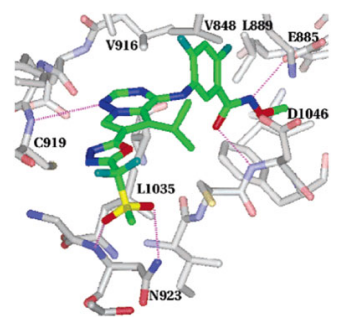

inserted in a hydrophobic pocket formed partially by the C-helix (Fig. 5).

Mastalerz lab developed $\mathbf{1 4}$ and $\mathbf{1 5}$ as dual inhibitors of EGFR and HER2 by modifications of earlier compound $\mathbf{1 3}$ in two different reports. In one report, $\mathbf{1 4}$ was shown as a lead [79] whereas $\mathbf{1 5}$ was reported as a lead in the second report [80] (Fig. 4). Both compounds showed comparable activities for both kinases but in cellular assay $\mathbf{1 5}$ was more potent than 14 on N87 cells. In N87 human gastric carcinoma and GEO human colon carcinoma athymic mouse xenograft models 15 showed TGI of 180 and $85 \%$ at dose loading of $180 \mathrm{mg} / \mathrm{kg}$ and $240 \mathrm{mg} / \mathrm{kg}$, respectively.

Fink et al. reported compound $\mathbf{1 6}$ as a dual inhibitor of HER2 and EGFR [81]. It inhibited both HER2 and EFFR with $\mathrm{IC}_{50}$ values of 0.01 and $0.006 \mu \mathrm{M}$, respectively. 16 was also active in cell assays carried out on N87 cells $\left(\mathrm{IC}_{50}=\right.$ $0.12 \mu \mathrm{M})$. A significant tumor growth inhibition was noticed in EGFR driven GEO colon tumor xenograft mice model. The in vivo and in vitro activities of $\mathbf{1 6}$ were much better than 17, a lead compound discovered by the same group previously [82] (Fig. 6).

Cai et al. designed and synthesized some pyrrolotriazine derivatives containing $N$-cyclopropylamides as VEGFR-2 kinase inhibitors which led to the discovery of 18 as a nanomolar inhibitor of VEGFR-2 $\left(\mathrm{IC}_{50}=11 \mathrm{nM}\right)$. Compound 18 was highly selective over CYP3A4, human cytochrome CYP450 isozyme (Fig. 6) [83]. Compound 18 also showed potent activity in VEGF-stimulated HUVEC proliferation assay. In the L2987 human lung carcinoma xenograft model in athymic mice, $\mathbf{1 8}$ showed
Table 2 VEGFR-2 and FGFR-1 biochemical and cellular potencies of compounds 6, 7, and 8

\begin{tabular}{llllll}
\hline Entry & \multicolumn{2}{l}{$\mathrm{IC}_{50}(\mathrm{nM})$} & & \\
\cline { 2 - 3 } & \multicolumn{2}{l}{ Kinase inhibition } & & \multicolumn{2}{l}{$\begin{array}{l}\text { Growth inhibition } \\
\text { of HUVECs }\end{array}$} \\
\cline { 2 - 3 } \cline { 5 - 6 } & VEGFR-2 & FGFR-1 & & VEGF & FGF \\
\hline $\mathbf{6}$ & 57 & 100 & & 17 & 21 \\
$\mathbf{7}$ & 16 & 16 & & 2.1 & 4.6 \\
$\mathbf{8}$ & 53 & 220 & 27 & 130 \\
\hline
\end{tabular}

$66 \%$ TGI at dose loading of $90 \mathrm{mg} / \mathrm{kg}$ with no adverse effects.

c-Mesenchymal-epithelial transition factor (c-Met also known as hepatocyte growth factor receptor is a protein tyrosine kinase that in humans is encoded by the MET gene [84]. c-Met involvement is crucial for the formation, metastasis, and invasion of various malignant tumors thus emerged as an attractive therapeutic target for cancer treatment [85]. Last year FDA approved Tabrecta (capmatinib), a c-Met inhibitor for the treatment of adult patients with non-small cell lung cancer (NSCLC) [86]. Shi et al. synthesized some pyrrolo[1,2-f][1,2,4]triazine derivatives as inhibitors of c-Met and VEGFR-2 [87]. Compound 19 showed micromolar activities against c-Met and VEGFR-2 with $\mathrm{IC}_{50}$ values of $2.3 \pm 0.1 \mathrm{nM}$ and $5.0 \pm 0.5 \mathrm{nM}$, respectively. The kinase activity of $\mathbf{1 9}$ was not better than Foretinib (Fig. 7). $\mathrm{IC}_{50}$ values of $0.71 \pm 0.16 \mathrm{nM}$ and $37.4 \pm$ $0.311 \mathrm{nM}$ were observed against BaF3-TPR-Met and 


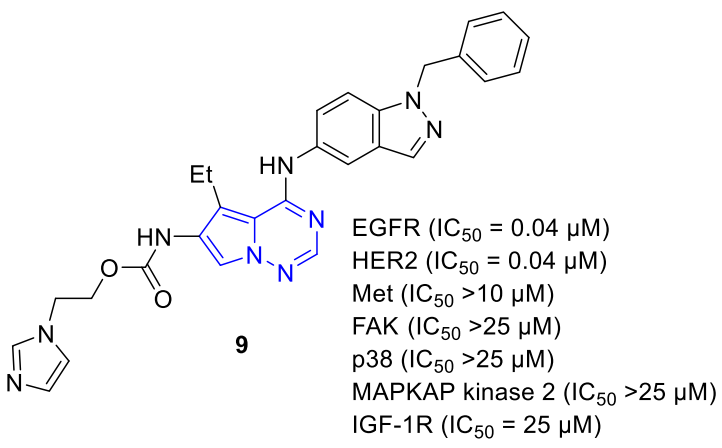

Fig. 3 Structure and activity of compound 9

HUVEC-VEGFR2 cells treated with 19. The docking study showed 19 occupied the same binding sites as Foretinib on c-Met and VEGFR-2. Compound 19 also showed good pharmacokinetic profile in SD rats after oral and intravenous injection (iv).

Schroeder et al. designed and synthesized some C-5 and C- 6 substituted pyrrolotriazine derivatives and evaluated their activity against Met kinase [88]. Among them, compound 20 displayed good inhibitory activity against Met kinase $\left(\mathrm{IC}_{50}=0.045 \mu \mathrm{M}\right)$ along with acceptable stability in mouse-liver microsome but with a poor clearance and oral bioavailability in PK studies. Compound 20 also showed poor cell permeability in Caco-2 assay $(\mathrm{Pc}<15 \mathrm{~nm} / \mathrm{s})$. An X-ray crystal structure of $\mathbf{2 0}$ complexes with the Met kinase suggested binding in ATP-binding sites (Fig. 8). The pyrrolotriazine scaffold formed the H-bonding with Met1160 and Pro1158 in the hinge region whereas the $\mathrm{NH}_{2}$ group attached to the piperidine ring formed H-bonding with Asp1164.

Anaplastic lymphoma kinase (ALK) also known as cluster of differentiation 246 (CD246), discovered in 1994 is a tyrosine receptor kinase encoded by the ALK gene [89-91]. It has two main domains, intracellular (tyrosine kinase domain) and extracellular (ligand-binding domain). The intracellular tyrosine kinase domain shares a high degree of similarity with insulin-like growth factor-1 receptor (IR) [92]. Axitinib, Brigatinib, Ceritinib, Crizotinib, Lorlatinib are the FDA-approved ALK inhibitors currently in clinical use for the treatment of NSCLC [37]. Ott et al. synthesized 2,7-disubstitutedpyrrolo[2,1-f][1,2,4]triazine scaffold containing molecules as potent ALK inhibitors [93]. Many compounds displayed well in vitro as well as in vivo efficacy. Compound 21 (Fig. 9) showed nanomolar activity against ALK $\left(\mathrm{IC}_{50}=10 \pm 2 \mathrm{nM}\right)$ with high selectivity over insulin-like growth factor-1 receptor $\left(\mathrm{IC}_{50}=1137 \pm\right.$ $398 \mathrm{nM}$ ). The compound 21 inhibited ALK-positive ALCL cells, Karpas-299 $\left(\mathrm{IC}_{50}=477 \mathrm{nM}\right)$ and Sup-M2 $\left(\mathrm{IC}_{50}=87 \mathrm{nM}\right)$ cells dose-dependently but did not inhibit
ALK-negative K562 cells at concentrations up to $3000 \mathrm{nM}$, indicating 21 inhibited ALK-positive ALCL cells primarily through inhibiting NPM-ALK activity. Compound 21 also showed good oral bioavailability in mice $(F=0.38)$. Oral dosing of 21 in SCID mice in a xenograft model (SUP-M2) inhibited tumor growth at 10 , 30 , and $55 \mathrm{mg} / \mathrm{kg}$ dose loading with no observable toxicity or body-weight loss.

Mesaros and co-workers discovered compound 22 as a potent ALK inhibitor displaying $\mathrm{IC}_{50}$ of $6 \mathrm{nM}$ along with high selectivity over IR (Fig. 9) [94]. In PK studies, 22 showed good iv half-life $\left(t_{1 / 2}=3.4 \mathrm{~h}\right)$, low clearance $(12 \mathrm{~mL} / \mathrm{min} / \mathrm{kg})$ and good stability in rat liver microsomes. Compound $\mathbf{2 2}$ inhibited tumor growth in ALK-driven tumor xenograft dose-dependently in mice.

Mesaros et al. discovered isomeric compounds 23 and $\mathbf{2 4}$ (Fig. 10) as potent inhibitors of ALK displaying ALK enzyme inhibitory activities with $\mathrm{IC}_{50}$ values of 3 and $5 \mathrm{nM}$, respectively [95]. Both compounds also displayed good activity on ALK cell lines. Change of cis (23) to trans (24) geometry did not deteriorate selectivity over IR or other kinases. When tested for in vivo efficacy in ALK-driven Sup-M2 tumor xenografts in SCID mice, 24 (trans-isomer) showed better tumor growth inhibition $(75-87 \%$ at $30 \mathrm{mg} /$ $\mathrm{kg}$ ) than $\mathbf{2 3}$ (cis isomer) at the same dosing.

The insulin-like growth factor 1 (IGF-1) receptor is a transmembrane tyrosine receptor kinase found on the surface of human cells [96-98]. It is activated by insulin-like growth factor 1 (IGF-1) and related hormone IGF-2. IGF-1 induces hypertrophy of skeletal muscle and other target tissues and plays an important role in cell growth. The IGF$1 \mathrm{R}$ is implicated in several cancers including breast, prostate, and lung [99]. The similar ATP binding sites of IGF$1 \mathrm{R}$ and the insulin receptor (IR) are hurdles in designing IGF-1R specific inhibitors. So far, no drug has been approved by FDA as an inhibitor of IGF-1. AG538, AG1024, and NVP-AEW541 are the potent IGF-1 inhibitors currently under clinical trials [100-102].

Wittman and co-workers discovered 2,4-disubstituted pyrrolo-[1,2-f][1,2,4]triazine $\mathbf{2 5 ( B M S - 7 5 4 8 0 7 )}$ as an inhibitor of IGF-1R $\left(\mathrm{IC}_{50}=2 \mathrm{nM}\right)$ (Fig. 11). 25 showed high selectivity over CDK2E (inhibition of CDK2E also inhibits IGF-Sal cell lines) and showed nanomolar potency on IGFSal cell lines $\left(\mathrm{IC}_{50}=7 \mathrm{nM}\right)$ [103]. 25 was also evaluated for in vivo efficacy in the transgenic-derived IGF-Sal tumor model. Complete tumor growth inhibition was observed in mice at a dosing of $6.25 \mathrm{mg} / \mathrm{kg}$. The crystal structure of $\mathbf{2 5}$ co-crystallized with the kinase domain of IGF-1R revealed that the cyclopropyl group occupied the shallow "gatekeeper" region of the kinase, whereas fluoropyridyl amide was extended into the sugar pocket (Fig. 11). H-bonding with Met1052 and Glu1050 in the hinge region was crucial for high activity. 
Fig. 4 Structures and activities of compounds 10-15<smiles>[R]c1cn2ncnc(Nc3ccc4c(cnn4Cc4cccc(F)c4)c3)c2c1[R]</smiles>

10; $\mathrm{R}=\mathrm{Me}, \mathrm{R}^{\prime}=\mathrm{CO}_{2} \mathrm{Et}$;

EGFR $\left(I_{50}=0.31 \mu \mathrm{M}\right)$, HER2 $\left(\mathrm{IC}_{50}=0.20 \mu \mathrm{M}\right)$

11; $\mathrm{R}=\mathrm{OMe}, \mathrm{R}^{\prime}=\mathrm{CO}_{2} \mathrm{Et}$;

EGFR $\left(I C_{50}>1 \mu \mathrm{M}\right)$, HER2 $\left(\mathrm{IC}_{50}>1 \mu \mathrm{M}\right)$

12; $\mathrm{R}=\mathrm{CO}_{2} \mathrm{Et}, \mathrm{R}^{\prime}=\mathrm{Me}$;

$\operatorname{EGFR}\left(\mathrm{IC}_{50}=0.47 \mu \mathrm{M}\right), \operatorname{HER} 2\left(\mathrm{IC}_{50}=0.63 \mu \mathrm{M}\right)$

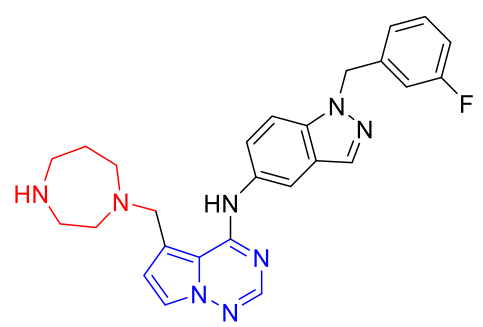

14

HER2 $\left(\mathrm{IC}_{50}=0.027 \mu \mathrm{M}\right)$

$\operatorname{EGFR}\left(\mathrm{IC}_{50}=0.033 \mu \mathrm{M}\right)$

$\mathrm{N} 87\left(\mathrm{IC}_{50}=0.11 \mu \mathrm{M}\right)$
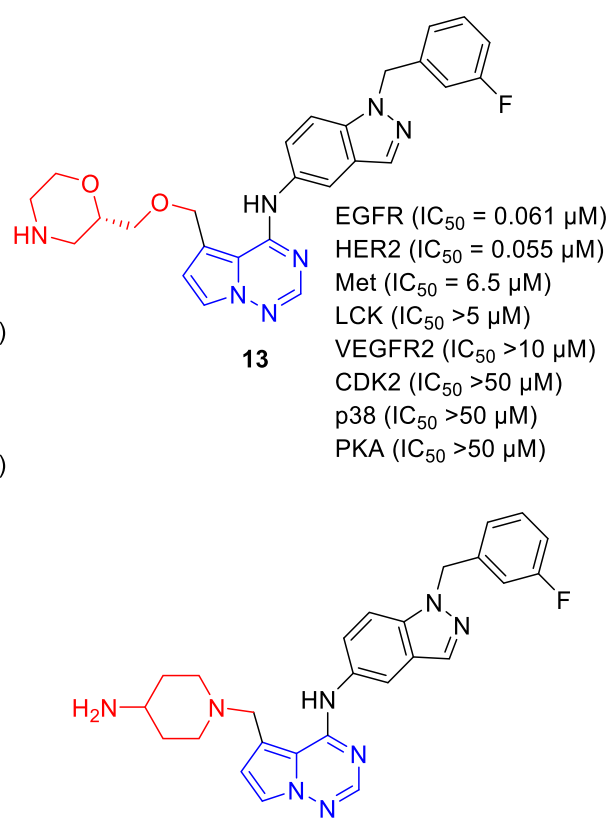

15

HER2 $\left(\mathrm{IC}_{50}=0.023 \mu \mathrm{M}\right)$ $\operatorname{EGFR}\left(\mathrm{IC}_{50}=0.035 \mu \mathrm{M}\right)$ $\mathrm{N} 87\left(\mathrm{IC}_{50}=0.035 \mu \mathrm{M}\right)$
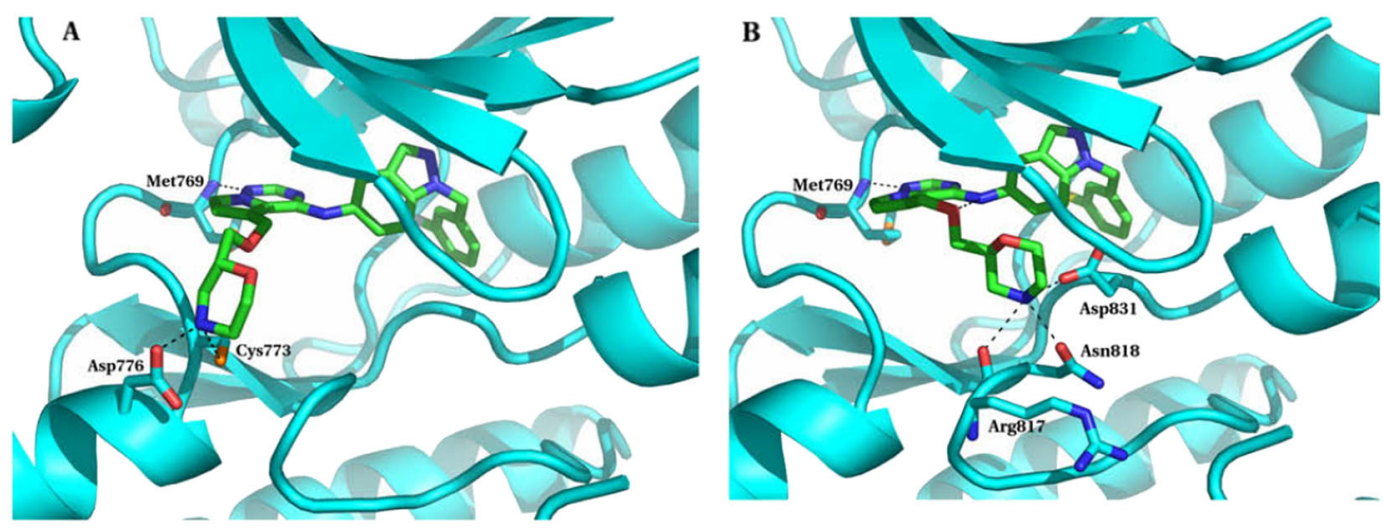

Fig. 5 Predicted binding modes of compound $\mathbf{1 3}$ modeled in the X-ray structure of the lapatinib/EGFR kinase complex (Figure reproduced with the permission of the original publisher)

\section{Non-receptor tyrosine kinase inhibitors}

Janus kinase (JAK) is a family of non-receptor tyrosine kinases that transduce cytokine-mediated signals through the JAK-STAT signaling pathway [104, 105]. The JAK family of proteins has four members, JAK1, JAK2, JAK3, and tyrosine kinase 2 (TYK2). JAKs are involved in different inflammatory, autoimmune diseases, and malignancies. Baricitinib (JAK1/2 inhibitor for Rheumatoid arthritis) [106], Fedratinib (JAK2 inhibitor for Myelofibrosis) [107], Ruxolitinib (JAK 1/2/3 inhibitor for Myelofibrosis, polycythemia vera), and Tofacitinib (JAK3 inhibitor for Rheumatoid arthritis) [108] are the JAK inhibitors currently in clinical use. Harikrishnan et al. synthesized some pyrrolo[1,2-f]triazines and evaluated them against different isoforms of JAK [109]. Compounds 26, 27, and 28 displayed potent activities against JAK2 over JAK1 and JAK3 (Fig. 12). Although compound $\mathbf{2 6}$ showed the most potent activity and selectivity for JAK2 27 was the most active compound in cellular assay when tested on SET-2 cell lines. X-ray crystal structure of pyrrolotriazine $\mathbf{2 8}$ docked on JAK2 showed that the pyrazole basic nitrogen accepts a hydrogen bond from Leu932 amidic $\mathrm{NH}$ whereas pyrazole $\mathrm{NH}$ donates a hydrogen bond to the carbonyl of Glu930 in the hinge region. Unfortunately, all compounds displayed poor metabolic stability. 
Fig. 6 Structures and activities of compounds 16-18
Fig. 7 A Structure and kinase activity of $\mathbf{1 9}$ and Foretinib; B 3D model depicting the binding of compound 19 and Foretinib with c-Met (Figure reproduced with the permission of the original publisher)<smiles>NC1CCN(Cc2ccn3ncnc(Nc4ccc(F)c(Cl)c4)c23)CC1</smiles>

$\mathrm{IC}_{50}(\mu \mathrm{M})$

HER2 $=0.01$, EGFR $=0.006, \mathrm{~N} 87=0.12$

GEO MED $=15 \mathrm{mg} / \mathrm{kg}$<smiles>Cc1c(NC(=O)OCC2COCCN2)cn2ncnc(Cc3ccc4c(cnn4Cc4cccc(F)c4)c3)c12</smiles>

$\mathrm{IC}_{50}(\mu \mathrm{M})$

HER2 $=0.03$, EGFR $=0.020, \mathrm{~N} 87=0.42$

GEO MED $=120 \mathrm{mg} / \mathrm{kg}$<smiles>CC(C)c1c(-c2nnc(OC3CCNCC3)o2)cn2ncnc(Nc3cc(C(=O)NC4CC4)c(F)cc3F)c12</smiles>

\begin{tabular}{ccc}
\multicolumn{3}{c}{$\mathrm{IC}_{50}(\mathrm{nM})$} \\
\hline VEGFR-2 & CYP3A4 & HUVEC \\
11 & 5000 & 23
\end{tabular}

(A)

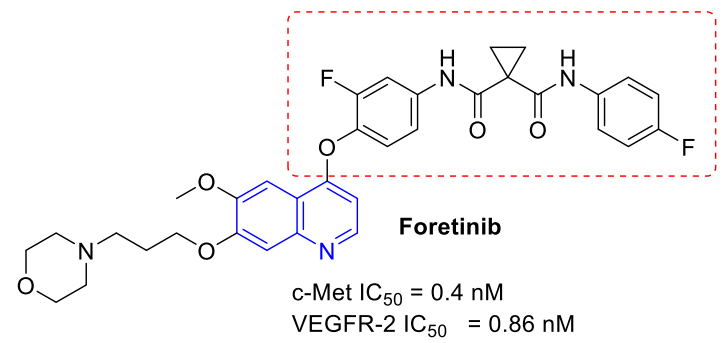

VEGFR-2 IC $50=0.86 \mathrm{nM}$

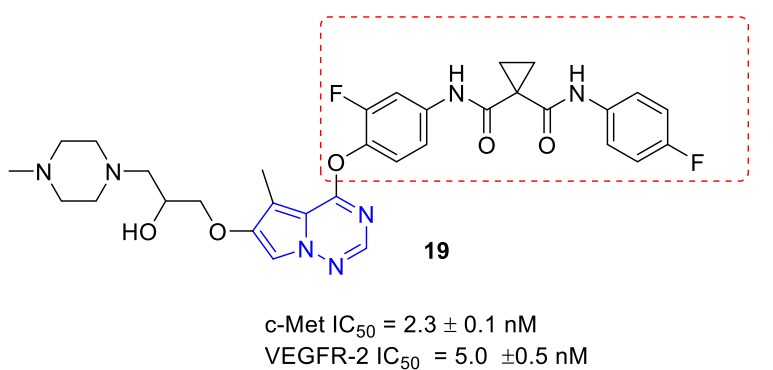

(B)
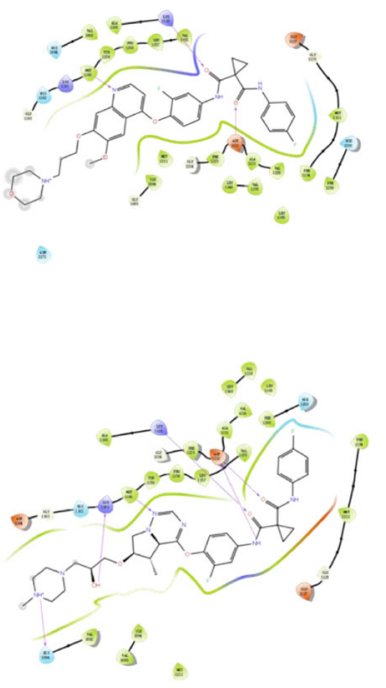

Weinberg Lab developed some 2,7-Pyrrolo[2,1-f] $[1,2,4]$ triazines as JAK2 inhibitors [110]. Lead compounds were also checked for liver microsome stability by measuring their ability to form Glutathione (GSH) adduct. Compound 29 exhibited JAK2 inhibition with an $\mathrm{IC}_{50}$ value of $0.17 \pm 0.03 \mathrm{nM}$ along with significantly low glutathione adduct formation (Fig. 12) [111].

\section{Serine/threonine kinase inhibitors}

The Aurora kinases are serine/threonine kinases that are crucial for cell proliferation [112]. Aurora kinases regulate cell cycle transit from G2 through cytokinesis. In humans three classes of aurora kinases are found namely, aurora kinase A, aurora kinase B, and aurora kinase C [113]. 
Fig. 8 A Structure and Met kinase inhibitory activity of compound 20; B X-ray cocrystal structure of compound $\mathbf{2 0}$ bound to the Met kinase domain (triple mutant) (Figure reproduced by the permission of the original publisher)
(A)<smiles>C[R16](C)(C)O[14C](C)(C)O[Na]</smiles>

(B)

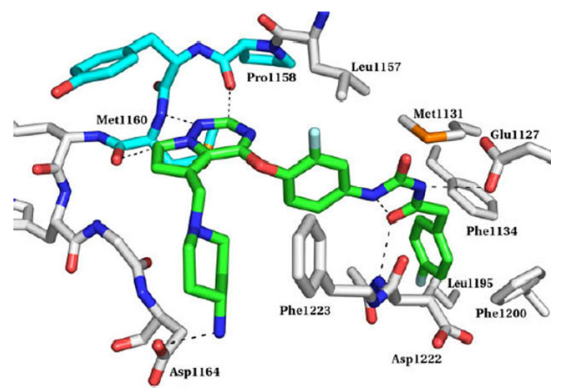<smiles>COc1cc(N2CCN(CC(C)O)CC2)ccc1Nc1ncc2ccc(-c3ccccc3N(C)S(C)(=O)=O)n2n1</smiles>

\begin{tabular}{lccc} 
ALK IC $_{50}(\mathrm{nM})$ & Cell IC $_{50}(\mathrm{nM})$ & $\mathrm{IR} I \mathrm{C}_{50}(\mathrm{nM})$ & $\mathrm{F}$ \\
\hline $10 \pm 2$ & 60 & $1137 \pm 398$ & 0.38
\end{tabular}

Karpas-299 $\left(\mathrm{IC}_{50}=477 \mathrm{nM}\right)$ Sup-M2 $\left(\mathrm{IC}_{50}=87 \mathrm{nM}\right)$
Anti-tumor Efficacy

$10 \mathrm{mg} / \mathrm{kg}=35 \% \mathrm{TGI}$ $30 \mathrm{mg} / \mathrm{kg}=81 \% \mathrm{TGI}$ $55 \mathrm{mg} / \mathrm{kg}=98 \% \mathrm{TGI}$

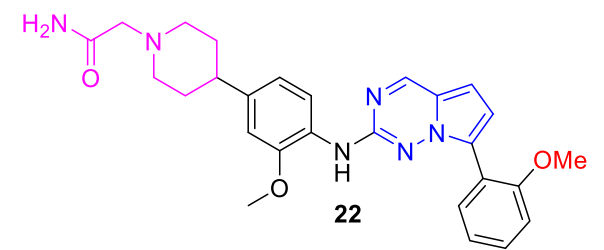

$\mathrm{IC}_{50}(\mathrm{nM})$

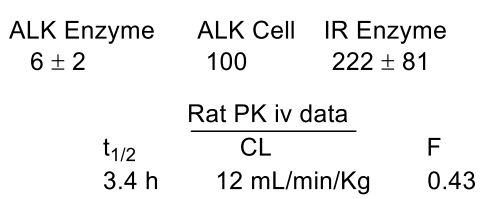

Fig. 9 Structures and ALK inhibitory activities of compounds 21 and 22

Fig. 10 Structures of compounds 23 and 24

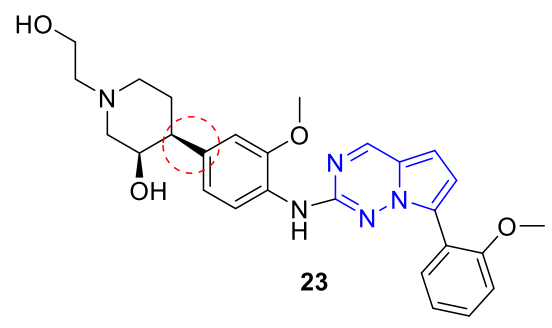

ALK Enzyme $\left(\mathrm{IC}_{50}=3 \mathrm{nM}\right)$ $\operatorname{ALK}$ Cell $\left(\mathrm{IC}_{50}=60 \mathrm{nM}\right)$

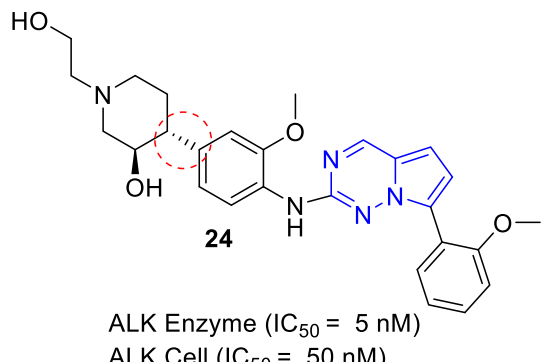

ALK Cell $\left(I_{50}=50 \mathrm{nM}\right)$

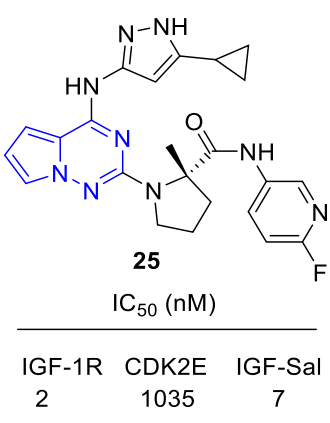

(A)

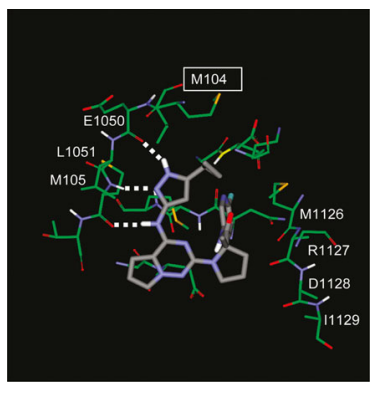

(B)
Fig. 11 A Structure and activity of 25; B X-ray crystal structure of 25 cocrystallized with IGF-1R) (Figure reproduced by the permission of the original publisher)
The former two types play a central role in mitosis, whereas the last one plays an important role in meiosis. Overexpression or gene amplification of aurora kinases is observed in several cancers. ZM447439 [114], Hesperadin [115], and Tozasertib [116] are the three potent aurora kinases inhibitors under clinical trials. Abraham et al. synthesized pyrrolotriazine 31, 32, 33, and $\mathbf{3 4}$ (Fig. 13) as potent pan-Aurora kinase inhibitors by structural modifications of their lead molecule $\mathbf{3 0}$ [117]. Compounds $\mathbf{3 1}$ $\left(K_{\mathrm{d}}=7 \mathrm{nM}\right)$ and $32\left(K_{\mathrm{d}}=9 \mathrm{nM}\right)$ were better than $\mathbf{3 0}$ against aurora kinase A whereas $\mathbf{3 4}$ showed better aurora kinase B inhibition $\left(K_{\mathrm{d}}=7 \mathrm{nM}\right)$ than $1\left(K_{\mathrm{d}}=20 \mathrm{nM}\right)$ along with high activity on HCT-116 cells (Table 3 ). The new analogs also showed an improved PK profile when 
Fig. 12 A Structures and activities of compounds 26-29; B X-ray crystal structure of pyrrolotriazine 28 bound to JAK2 (Figure reproduced with the permission of the original publisher)
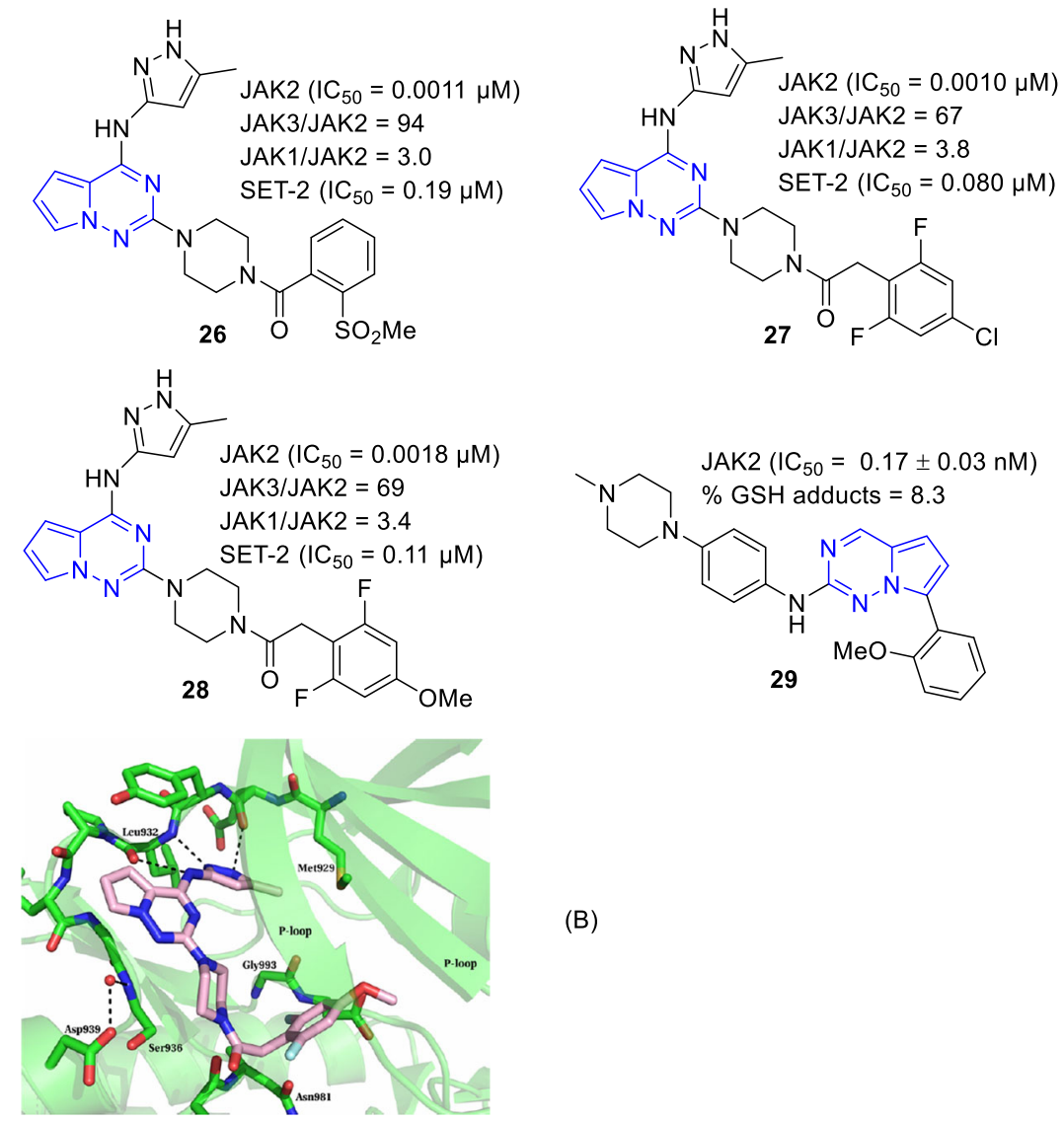

(B)

compared to 30. In vivo studies carried out with 34 in a flank-tumor xenograft model in nude mice using the HCT116 cells resulted in a dose-dependent tumor growth inhibition but along with severe body loss at high dosing.

The same research group also discovered $\mathbf{3 5}$ and $\mathbf{3 6}$ as potent aurora kinase inhibitors (Fig. 14) [118]. Both compounds inhibited Aurora kinase A and B in nanomolar potency but with high selectivity for aurora B. Both compounds were also active at cellular levels when evaluated on HCT-116 cells either by measuring the inhibition of histone $\mathrm{H} 3$ phosphorylation mediated by aurora kinase B14 or the inhibition of cell proliferation. Both compounds showed high efficacy in the in vivo studies carried out in nude rats in a xenograft model with no significant body weight loss or lethality. Both compounds also showed good selectivity over a panel of 359 kinases.

Mitogen-activated protein kinase kinase kinase kinase 4 (MAP4K4) also known as hepatocyte progenitor kinaselike/germinal center kinase-like kinase and Nck-interacting kinase is a serine/threonine kinase that is involved in cell proliferation, migration, and adhesion [119]. MAP4K4 activity is implicated in systemic inflammation, metabolic disorders, cardiovascular diseases, and cancer. There is very limited information on the role of MAP4K4 in cancer [120]. Wand et al. discovered compounds $\mathbf{3 7}$ and $\mathbf{3 8}$ (Fig. 15) as potent inhibitors of MAP4K4 [121]. Both compounds inhibited MAP4K4 effectively with $\mathrm{IC}_{50}$ values of 4 and $5 \mathrm{nM}$, respectively. In PK studies, 37 showed much higher oral bioavailability $(F=0.72)$ than $\mathbf{3 8}(F=0.12)$.

Phosphoinositide 3-kinases (PI3Ks) discovered by Lewis Cantley et al. are the family of enzymes involved in cellular functions viz. cell growth, proliferation, survival, differentiation, motility, and intracellular trafficking [122-124]. Based upon a primary structure, regulation, and in vitro lipid substrate specificity, the PI3K family is divided into four main classes. PI3Ks are activated by various factors and cytokines that result in the activation of serine/threonine kinase AKT and other downstream effector pathways. The early clinical trials with pan-PI3K inhibitors were halted due to high toxicities and modest antitumor effects but there have been continued efforts to develop safer and isoformselective inhibitors to improve the therapeutic index. Recently three PI3K inhibitors namely, idelalisib, copanlisib, and duvelisib) are approved by FDA [125-127].

Dugar and co-workers discovered compound $\mathbf{3 9}$ as an inhibitor of PI3K $\alpha\left(\mathrm{IC}_{50}=0.02 \mu \mathrm{M}\right)$ (Fig. 16) [128]. When evaluated for in vitro metabolic stability in liver microsomal enzymes of three species (mouse, dog, and human) it showed more stability in human liver microsomes compared to other species. In the cellular assay, it inhibited human 
Fig. 13 Structures of compounds 30-34<smiles></smiles><smiles>Cc1cc(Nc2nc(Sc3ccc(NC(=O)N4C[C@@H](O)CC4Oc4ccc(F)cc4)cc3)nn3cccc23)n[nH]1</smiles>

Table 3 The activities of compounds $30-34$ on aurora kinase and HCT-116 cells

\begin{tabular}{|c|c|c|c|c|c|c|}
\hline \multirow[t]{2}{*}{ Entry } & \multirow[t]{2}{*}{ Compd } & \multicolumn{3}{|c|}{$\begin{array}{l}\text { Aurora } \\
K_{\mathrm{d}}(\mathrm{nM})\end{array}$} & \multicolumn{2}{|c|}{ Cell $\mathrm{IC}_{50}(\mathrm{nM})$} \\
\hline & & A & B & $\mathrm{C}$ & $\begin{array}{l}\text { pHH3 } \\
\text { (HCT-116) }\end{array}$ & $\begin{array}{l}\text { Proliferation } \\
\text { (HCT-116) }\end{array}$ \\
\hline 1 & 30 & 12 & 20 & 4 & 55 & 28 \\
\hline 2 & 31 & 7 & 4 & 5 & 190 & 75 \\
\hline 3 & 32 & 9 & 8 & 2 & 15 & 8 \\
\hline 4 & 33 & 12 & 5 & nd & 16 & 4 \\
\hline 5 & 34 & 15 & 8 & nd & 44 & 5 \\
\hline
\end{tabular}

ovarian cancer cell lines, A2780, SKOV3 (ovarian carcinoma cell line), and PC3 (human prostate cancer cell line) with $\mathrm{EC}_{50}$ values of $1.10,3.2,2.4 \mu \mathrm{M}$, respectively. It showed good selectivity over a panel of 23 kinases at $1 \mu \mathrm{M}$ concentration except for homologous PI3 kinases and mTOR.

Erra et al. discovered 40 (LAS191954) as a selective nanomolar inhibitor of $\mathrm{PI} 3 \mathrm{~K} \delta\left(\mathrm{IC}_{50}=2.6 \mathrm{nM}\right)$ for the treatment of inflammatory diseases (Fig. 16) [129]. 40 also showed nanomolar potency on THP-1 cells $\left(\mathrm{IC}_{50}=\right.$ $7.8 \mathrm{nM}$ ). The $\%$ metabolism (disappearance of parent compound after microsomal incubation) of 20 and $16 \%$ was observed in rats and humans microsomes, respectively. Compounds 40 exhibited a superior PK profile than Idelalisib in dogs and rats.

Bhide and co-workers discovered another pyrrolo[2,1-f] $[1,2,4]$ triazine based compound $\mathbf{4 1}$ as a nanomolar inhibitor of PI3K $\delta\left(\mathrm{IC}_{50}=2 \mathrm{nM}\right)$ (Fig. 17). 41 also inhibited human B-cell proliferation (hu B-cell prolif) and human whole blood assay measuring suppression of CD86 expression (hu WB CD86) with $\mathrm{IC}_{50}$ of 6 and $118 \mathrm{nM}$, respectively [130]. The selectivity of 41 against other isoforms ( $\alpha, \beta$, and $\gamma$ ) was 666,800 , and 130-fold, respectively. Compound $\mathbf{4 1}$ showed a good PK profile with clearance of $82.1 \mathrm{~mL} / \mathrm{min} / \mathrm{kg}, 6.2 \mathrm{~L} / \mathrm{kg}$ volume of distribution, 0.46 of fraction $(F)$, and a half-life of $1 \mathrm{~h}$. The efficacy of $\mathbf{4 1}$ in a mouse collagen-induced arthritis was found to be superior to methotrexate.

From the same team of researchers, another PI3K $\delta$ inhibitor, 42, with higher activity and selectivity over $\beta$ isoform than 41 was reported (Fig. 17) [131]. The cellular activity (B-cells) of $\mathbf{4 2}$ ( $\mathrm{IC}_{50}=5.8 \mathrm{nM}$ ) was slightly better than 41. Compound $\mathbf{4 2}$ exhibited good efficacy in a mouse $\mathrm{KLH}$ model at dose loading of $3 \mathrm{mg} / \mathrm{kg}$ (twice a day). Compound 42 was well tolerated after day-4 at a dose loading of $300 \mathrm{mg} / \mathrm{kg}$ (QD) in mice with no sign of morbidity or mortality indicating its high selectivity index. 
Marcoux et al. discovered selective PI3K $\delta$ inhibitor 44 by structural modification of their early hit $\mathbf{4 3}$ which was a potent and dual inhibitor of PI3K $\delta$ and $\gamma$ but selective for $\mathrm{PI} 3 \mathrm{~K} \alpha$ and $\mathrm{PI} 3 \mathrm{~K} \beta$. 43 showed weak inhibition in a $\mathrm{T}$ cell $\mathrm{hWB}$ IFN $\gamma \mathrm{X}$ assay as well as in a B cell hWB CD69 assay probably due to low cell permeability [132]. Compound 44 exhibited high potency compared to $\mathbf{4 3}$ and showed an outstanding kinome selectivity profile (Fig. 18). In human B cell proliferation assay it displayed an $\mathrm{IC}_{50}$ of $1 \mathrm{nM}$. Despite showing high potency and selectivity, compound 44 exhibited poor stability in liver microsomes.

Xiang et al. synthesized a series of 6-aminocarbonyl pyrrolo[2,1-f][1,2,4]triazine derivatives and evaluated their activity against all isoforms of PI3K. Initially compounds 45 was synthesized which exhibited potent activity against $\mathrm{p} 110 \alpha$ and $\mathrm{p} 110 \delta$ with $\mathrm{IC}_{50}$ of $122 \mathrm{nM}$ and $119 \mathrm{nM}$, respectively while requiring higher dose for $\mathrm{p} 110 \beta$ and p110 $\gamma$ inhibition ( $\mathrm{IC}_{50}=1293$ and $663 \mathrm{nM}$, respectively) (Fig. 19) [133]. 45 displayed good efficacy against human rhabdomyosarcoma Rh30 cells. By performing further SAR study compounds, 46 and 47 were developed (Fig. 19). Both compounds showed good efficacy in cellular assay when tested against a panel of cell lines, Rh30, BT-474, SK-BR-3, SKOV-3, and T47D LO2. The poor PK profile of 47 halted its further development.
Fig. 14 Structures, activities, and $\mathrm{PK}$ profile of compounds $\mathbf{3 5}$ and 36

Fig. 15 Structures, activity, and PK profiles of compounds 37 and 38
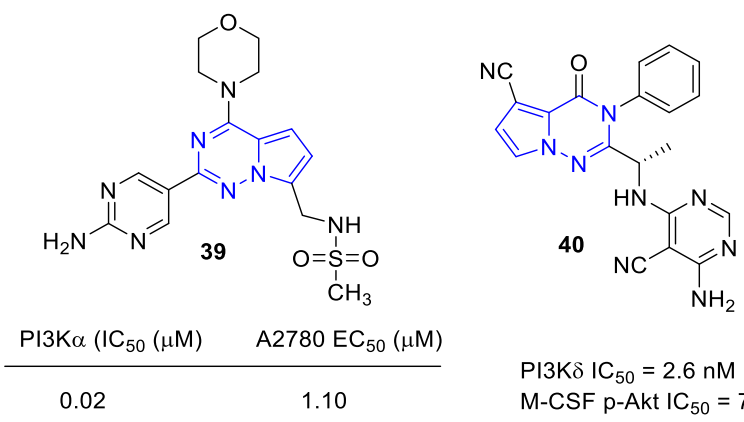

$\mathrm{PI} 3 \mathrm{~K} \delta \mathrm{IC}_{50}=2.6 \mathrm{nM}$ M-CSF p-Akt IC I0 $=7.8 \mathrm{nM}$

Fig. 16 Structure and PI3K inhibition of compounds 39 and 40 (LAS191954)

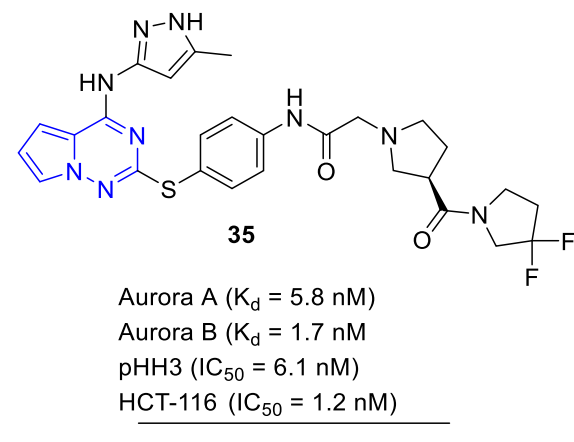

PK profile at dose loading $1 \mathrm{mg} / \mathrm{kg}$ in SD rats clearance $=21.05 \mathrm{~mL} \cdot \mathrm{min}^{-1} \cdot \mathrm{kg}^{-1}$ $\mathrm{Vd}=7 \mathrm{~L} / \mathrm{kg}$ $\mathrm{AUC}_{0-\infty}=1.4 \mu \mathrm{M} \cdot \mathrm{h}$ $\mathrm{t}_{1 / 2}=17.5 \mathrm{~h}$<smiles>Cc1cc(Nc2nc(Sc3ccc(NC(=O)CN4CC[C@H](C(=O)NC5CCCC5)C4)cc3)nn3cccc23)n[nH]1</smiles>

Aurora $A\left(K_{d}=9.3 n M\right)$

Aurora $B\left(K_{d}=1.9 \mathrm{nM}\right.$

$\mathrm{pHH} 3\left(\mathrm{IC}_{50}=3.0 \mathrm{nM}\right)$

HCT-116 $\left(\mathrm{IC}_{50}=2.3 \mathrm{nM}\right)$

PK profile at dose loading $1 \mathrm{mg} / \mathrm{kg}$ in SD rats clearance $=16.92 \mathrm{~mL} \cdot \mathrm{min}^{-1} \cdot \mathrm{kg}^{-1}$ $\mathrm{Vd}=3.42 \mathrm{~L} / \mathrm{kg}$ $\mathrm{AUC}_{0-\infty}=1.8 \mu \mathrm{M} . \mathrm{h}$ $t_{1 / 2}=9.4 h$

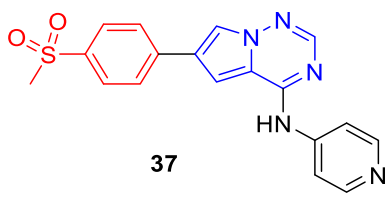

MAP4K4 LC3K $\left(\mathrm{IC}_{50}=4 \mathrm{nM}\right)$ Kinetic solubility $<1 \mu \mathrm{M}$ Mouse i.v. CLP at $1 \mathrm{mg} / \mathrm{kg}$ dose $=25 \mathrm{ml} / \mathrm{min} / \mathrm{kg}$ Vss $=1 \mathrm{~L} / \mathrm{kg}$ $\mathrm{F}, 25 \mathrm{mg} / \mathrm{kg}$ dose $=0.72$

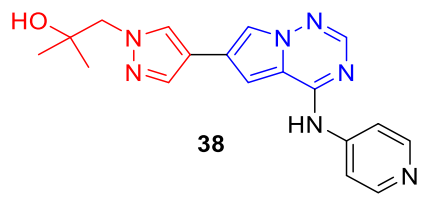

MAP4K4 LC3K $\left(\mathrm{IC}_{50}=2 \mathrm{nM}\right)$ Kinetic solubility $53 \mu \mathrm{M}$ Mouse i.v. CLP at $1 \mathrm{mg} / \mathrm{kg}$ dose $=78 \mathrm{ml} / \mathrm{min} / \mathrm{kg}$ $\mathrm{Vss}=15 \mathrm{~L} / \mathrm{kg}$ $\mathrm{F}, 25 \mathrm{mg} / \mathrm{kg}$ dose $=0.12$
Fig. 17 Structures and activities of compounds $\mathbf{4 1}$ and $\mathbf{4 2}$ 
Fig. 18 Structures and activities of compounds 43 and 44

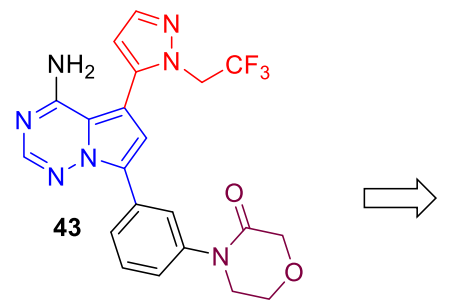

$\mathrm{PI} 3 \mathrm{~K} \delta \mathrm{IC}_{50}(\mathrm{nM})<0.2$

$\mathrm{PI} 3 \mathrm{~K} \gamma$ selectivity $>1000 \mathrm{x}$

PI3K $\alpha$ selectivity $>1000 x$

$\mathrm{P}$ I3K $\alpha$ selectivity $>1000 \mathrm{x}$

$\mathrm{PI} 3 \mathrm{~K} \delta \mathrm{INF} \gamma(\mathrm{nM})=20$

PI3K8WB CD69 $(\mathrm{nM})=7$
Fig. 19 Structures and antiproliferative activities of $\mathbf{4 5}$, 46, and 47

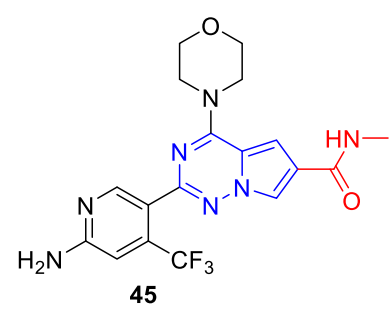

$\mathrm{Rh} 30\left(\mathrm{IC}_{50}=2.4 \pm 0.5 \mu \mathrm{M}\right.$ BT-474 $\left(\mathrm{IC}_{50}=2.4 \pm 1.1 \mu \mathrm{M}\right.$ SK-BR-3 $\left(\mathrm{IC}_{50}=2.4 \pm 0.5 \mu \mathrm{M}\right.$ SKOV-3 $\left(\mathrm{IC}_{50}=2.3 \pm 0.8 \mu \mathrm{M}\right.$ T47D $\left(\mathrm{IC}_{50}=0.8 \pm 0.1 \mu \mathrm{M}\right.$ $\mathrm{LO} 2=\left(\mathrm{IC}_{50}=10.6 \pm 0.5 \mu \mathrm{M}\right.$
Jia et al. used a combination of electronic density model and molecular docking and discovered pyrrolotriazinone containing compound $\mathbf{4 8}$ as a potent and selective PI3K $\gamma-$ PI3K $\delta$ dual inhibitor (Fig. 20) [134]. 48 exhibited potent inhibitory effects on basophil and B cell activation. In PK studies 48 displayed moderate clearance in rats and low clearance in dogs but high oral bioavailability $(F=1.08$ and 0.82 ) in rats and dogs, respectively).

Interleukin-1 receptor-associated kinase 4 (IRAK4) is a threonine/serine protein kinase that belongs to the IRAK family of proteins $[135,136]$. IRAK4 is the most upstream kinase in Toll/Interleukin-1 receptor signaling. IRAK4 possesses two main domains, a kinase domain, and a death domain. IRAK4 overactivation is linked with several autoimmune diseases and cancers. CA-4948, an IRAK4 inhibitor is in the early stages of clinical trials [137]. Degorce and coworkers discovered compounds 49 (IRAK4 $\mathrm{IC}_{50}=0.022 \mu \mathrm{M}$ ) and 50 (IRAK4 $\mathrm{IC}_{50}=0.094 \mu \mathrm{M}$ ) as potent IRAK4 inhibitors using a scaffold hopping strategy (Fig. 21) [138]. Both compounds displayed good selectivity over a panel of 126 kinases at $1 \mu \mathrm{M}$ concentration. Anti-tumor activity of $\mathbf{4 9}$ was evaluated in female SCID mice bearing OCILY10 tumors. Daily oral treatments with $49(200 \mathrm{mg} / \mathrm{kg})$ and ibrutinib
$(12 \mathrm{mg} / \mathrm{kg})$ resulted in TGI of $92 \%$ and $52 \%$, respectively. A combination of 49 and ibrutinib showed synergistic effects with TGI $>100 \%$ after 43 days.

\section{Non-kinase inhibitors}

The hedgehog signaling pathway transmits information to embryonic cells required for proper cell differentiation [139, 140]. Different concentrations of hedgehog signaling proteins are found in different parts of the embryo. The Hedgehog (Hh) signaling pathway was first identified in the common fruit fly. Mammals have three Hedgehog homologs, Desert (DHH), Indian (IHH), and Sonic (SHH). Among these SHH is the most studied. Several Hh signaling pathway inhibitors have been discovered for cancer therapy [141]. Vismodegib, (for basal cell carcinoma), Sonidegib FDA (basal cell carcinoma), and Itraconazole are the Hh signaling pathway inhibitory currently under clinical use [142]. Xin et al. synthesized some pyrrolo[2,1-f][1,2,4]triazine framework containing molecules and evaluated their $\mathrm{Hh}$ signaling pathway inhibitory activity using a luciferase reporter in NIH3T3 cell carrying a stably transfectedGli-reporter construct (Gli- 


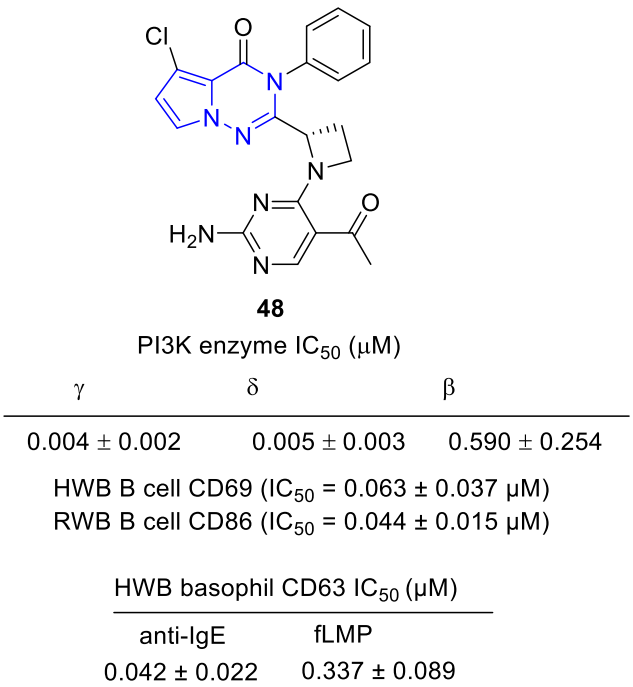

Fig. 20 Structure and activity of $\mathbf{4 8}$
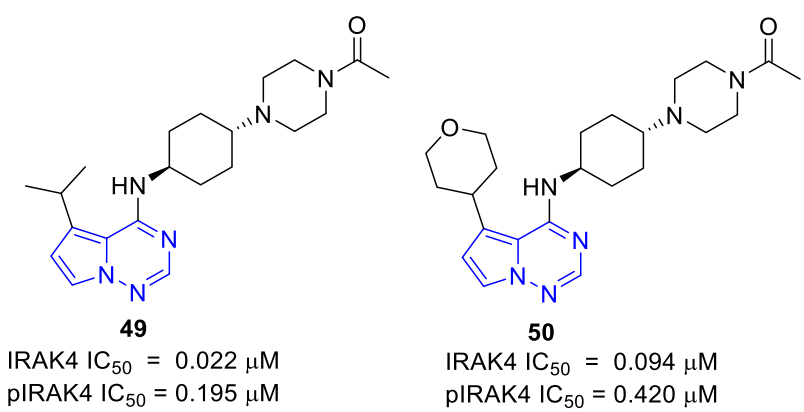

Fig. 21 Structures and activities of $\mathbf{4 9}$ and $\mathbf{5 0}$

luciferase reporter cell lines) [143]. Compound 51 was developed as the lead after a detailed SAR study. It showed an $\mathrm{IC}_{50}$ value of $0.83 \mathrm{nM}$ in the in vitro Gli-luciferase reporter assay. An area-under-curve of $2230.32 \mathrm{ng} . \mathrm{h} / \mathrm{mL}$ and clearance of $414.07 \mathrm{~mL} / \mathrm{h} / \mathrm{kg}$ were observed with $\mathbf{5 1}$ in PK studies (Fig. 22).

Kim et al. synthesized few compounds containing pyrrolotriazine-4-one scaffold and assessed their activities against Eg5 (also known as K1F11 or kinesin-5) [144]. Compound 52 (Fig. 22) was emerged as a lead which displayed potent activity in $\mathrm{Eg} 5$ ATPase $\left(\mathrm{IC}_{50}=0.06 \mu \mathrm{M}\right)$ and A2780 cell proliferation assays $\left(\mathrm{IC}_{50}=0.05 \mu \mathrm{M}\right)$. Clearance and $t_{1 / 2}$ values of $16 \pm 2.7 \mathrm{~mL} / \mathrm{min} / \mathrm{kg}$ and $4.5 \pm 1.6 \mathrm{~h}$ respectively were observed in pharmacokinetic studies performed in mice. In the in vivo studies, a T/C (treated/control) value of $163 \%$ was observed at iv dosing of $20 \mathrm{mg} / \mathrm{kg}$ in mice with P388 murine leukemia.

\section{Kinase design and SAR study}

It has been seen from several examples that the bulky group's substitution at C-4 and C-6 positions of pyrrolo [2,1-f][1,2,4]triazine is crucial to develop selective VEGFR2, EGFR, and c-Met inhibitors (Figs. 1-8, 23). Both positions (C-4 and C-6) can accommodate moderate to large substituents and their structural changes alter the activity/ selectivity of the inhibitor. In addition, there is a small room to adapt smaller substituents at the $\mathrm{C}-5$ position for improving the selectivity further (Fig. 23). The C-2 and C-7 positions of pyrrolo[2,1-f][1,2,4]triazine have not been explored yet for VEGFR2, EGFR, or c-Met selectivity. In contrast, the substitution at $\mathrm{C}-2$ and $\mathrm{C}-7$ positions of pyrrolo [2,1-f] $[1,2,4]$ triazine plays an important role to develop ALK selective inhibitors (Figs. 9, 10, 23). In general, large groups could be accommodated at the C-2 position compared to C-7. There is a single example of an IGF-1R inhibitor that contains pyrrolo[2,1-f][1,2,4]triazine scaffold, the results indicate that both $\mathrm{C}-2$ and $\mathrm{C}-4$ substitution lead to higher selectivity for IGF-1R (Figs. 11 and 23). In the case of non-receptor tyrosine kinase, the substitution at $\mathrm{C}-2$ and C-4 is the key for higher JAKs selectivity. In general, most of the modifications are done on the $\mathrm{C}-2$ position of pyrrolo[2,1-f][1,2,4]triazine whereas small groups such as amino pyrazole are placed at the $\mathrm{C}-4$ position (Figs. 12 and 23). Putting substituents at the $\mathrm{C}-7$ position (e.g., compound 29, Fig. 12) improves the selectivity of an inhibitor for JAK2 over the other isoforms. In the case of serine/threonine kinase inhibitors, the substitution at C-2 and C-4 makes the inhibitor more selective for aurora kinase. Interestingly, the substituents preference of inhibitors for aurora kinases is like JAKs). The substitution at C-6 further improves the activity (Table 3). The substitution at C-4 and C-6 is important to achieve higher MAP4K4 selectivity (Figs. 15 and 23). Interestingly, all the carbons of pyrrolo [2,1-f][1,2,4]triazine have been explored to get PI3K selective inhibitors (Figs. 16-21, 23). In general, most of the substituents used are small to moderate. Future design to develop more selective kinase inhibitors should focus on substituting the unexplored sites of pyrrolo[2,1-f][1,2,4] triazine for a specific kinase and also the modifications of groups at the appropriate positions.

\section{Conclusions and outlook}

The use of targeted therapy to treat cancer by targeting specific proteins or enzymes has gained much attention in the recent past when compared to other therapies. Several drugs are approved every year as kinase inhibitors to treat cancer. Most the kinase inhibitors contain one or more fused heterocycles, and pyrrolo[2,1-f][1,2,4]triazine is one among them. We have seen that several small organic molecules containing pyrrolo[2,1-f] $[1,2,4]$ triazine scaffold have shown potent in vitro and in vivo activities against a variety of cancer cells and tumors. The compounds have potently 
Fig. 22 Structures, activities, and PK profiles of $\mathbf{5 1}$ and $\mathbf{5 2}$<smiles>Cc1ccc(CN2CCOCC2)cc1NC(=O)c1ccc(Cc2nc(-c3ccc(C(=O)OC(F)(F)F)cc3)c3cccn3n2)cc1</smiles>

51

Gli-luc reporter $\mathrm{IC}_{50}(\mathrm{nM})=0.83 \mathrm{nM}$

$\mathrm{C}_{\max }=2720.52 \mathrm{ng} / \mathrm{mL}$

$\mathrm{AUC}=2230.32 \mathrm{ng} \cdot \mathrm{h} / \mathrm{mL}$

$\mathrm{V}_{\mathrm{z}}=5230.65 \mathrm{~mL} / \mathrm{kg}$

$\mathrm{Cl}=414.07 \mathrm{~mL} / \mathrm{h} / \mathrm{kg}$

$\operatorname{MRT}(0-t)=4.83 \mathrm{~h}$

$\mathrm{t}_{1 / 2}=8.86 \mathrm{~h}$

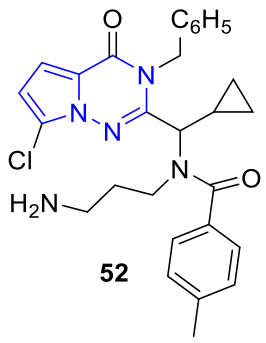

$\mathrm{IC}_{50}(\mu \mathrm{M})$

\begin{tabular}{cc}
\hline Eg5 ATPase & A2780 cytotoxicity \\
\hline $0.06 \pm 0.003$ & $0.05 \pm 0.025$ \\
& Clearance $(\mathrm{mL} / \mathrm{min} / \mathrm{kg})=16 \pm 2.7$ \\
Vss $(\mathrm{L} / \mathrm{kg})=5.9 \pm 0.92$ \\
MRT $(\mathrm{h})=6.5 \pm 2.3$ \\
$\mathrm{t}_{1 / 2}(\mathrm{~h})=4.5 \pm 1.6$ \\
$\% \mathrm{~T} / \mathrm{C}=163$ at $20 \mathrm{mg} / \mathrm{kg}$ dose loading
\end{tabular}

Fig. 23 A corelation of kinase activity/selectivity and substitution pattern/size on the pyrrolo[2,1-f][1,2,4]triazine scaffold

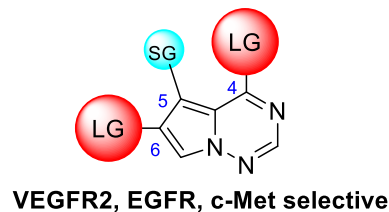

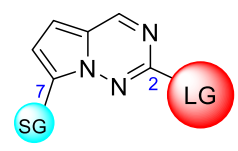

ALK selective

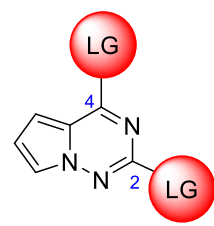

IGF-1R selective
SG - Smalll Group

LG - Large Group

Receptor tyrosine kinase inhibitors

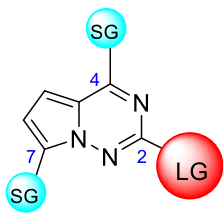

JAKs selective

Non-receptor tyrosine kinase inhibitors

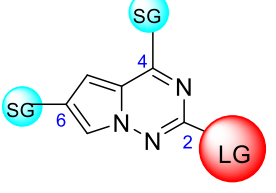

Aurora kinase selective<smiles>[CH]c1cc2c([Hg])ncnn2c1</smiles>

MAP4K4 selective

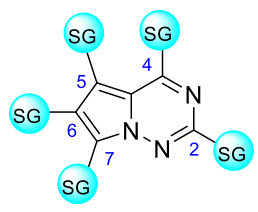

PI3K selective
Serine/threonine kinase inhibitors inhibited receptor tyrosine kinase inhibitors viz. EGFR, VEGF, FGFR, c-Met, ALK, IGF-1 as well as non-receptor tyrosine kinase such as JAK. This class of compound is also active against serine/threonine kinases including aurora kinases, MAP4K4, PI3Ks, and IRAK4. Most of the compounds are ATP-competitive inhibitors. A few compounds containing pyrrolo[2,1-f][1,2,4]triazine scaffold have also inhibited the Eg5 and hedgehog signaling pathway that is dysregulated in some cancers.

Future studies should also focus on developing irreversible or covalent inhibitors to target kinases [145]. All the examples discussed in this review article are of reversible inhibitors which means these inhibitors follow occupancy-driven pharmacology wherein the efficacy of the inhibitor correlates with 
its off constant thus requiring a higher dose of a drug to maximally inhibit the kinase [146]. In contrast, the efficacy of a covalent or irreversible inhibitor depends upon its inhibitor constant as well as the proximity of its electrophilic component viz. Michael acceptor and the nucleophilic component of the protein such as sulphydryl group of the surface exposed cysteine residue. A Bruton's tyrosine kinase inhibitor, Ibrutinib is an excellent example of a covalent kinase inhibitor that has been approved by the FDA for the treatment of mantle cell lymphoma, chronic lymphocytic leukemia, and Waldenström's macroglobulinemia [147]. Future studies should also focus on converting the kinase inhibitor into a kinase selective degrader. The PROTAC [148] and molecular Glue [149] approaches rely on artificially inducing the degradation of a targeted protein by hijacking cellular quality control machinery. To develop a selective kinase degrader, the solvent-exposed sites of pyrrolo[2,1-f][1,2,4]triazine could be extended and connected to E3 ligase recruiting ligands such as VHL or thalidomide through a linker of an appropriate length [150]. We believe that this review article will be useful to medicinal chemists in designing better kinase inhibitors/degraders containing pyrrolo[2,1-f][1,2,4]triazine scaffold for cancer therapy.

\section{Compliance with ethical standards}

Conflict of interest The authors declare that they have no conflict of interest, financial or otherwise.

Publisher's note Springer Nature remains neutral with regard to jurisdictional claims in published maps and institutional affiliations.

\section{References}

1. Sung H, Ferlay J, Siegel RL, Laversanne M, Soerjomataram I, Jemal A, et al. Global Cancer Statistics 2020: GLOBOCAN estimates of incidence and mortality worldwide for 36 cancers in 185 countries. CA Cancer J Clin. 2021;71:209-49. https://doi. org/10.3322/caac. 21660

2. Fisher B. Biological research in the evolution of cancer surgery: a personal perspective. Cancer Res. 2008;68:10007-20. https:// doi.org/10.1158/0008-5472.Can-08-0186

3. Li Y, Atkinson K, Zhang T. Combination of chemotherapy and cancer stem cell targeting agents: preclinical and clinical studies. Cancer Lett. 2017;396:103-9. https://doi.org/10.1016/j.canlet. 2017.03.008

4. Coccolini F, Fugazzola P, Ansaloni L, Sartelli M, Cicuttin E, Leandro G, et al. Advanced gastric cancer: the value of systemic and intraperitoneal chemotherapy. Acta Biomed. 2018;89:104-9. https://doi.org/10.23750/abm.v89i8-S.7904

5. Divya U, Vibha, Sarbjit S, Manpreet K. Schiff bases and their metal complexes as anti-cancer agents: a review. Curr Bioact Compd. 2015;11:215-30. https://doi.org/10.2174/ 1573407212666151214221219

6. Bhattarai D, Singh S, Jang Y, Hyeon Han S, Lee K, Choi Y. An insight into drug repositioning for the development of novel anti- cancer drugs. Curr Top Med Chem. 2016;16:2156-68. https:// doi.org/10.2174/1568026616666160216153618

7. Baskar R, Lee KA, Yeo R, Yeoh KW. Cancer and radiation therapy: current advances and future directions. Int J Med Sci. 2012;9:193-9. https://doi.org/10.7150/ijms.3635

8. Student S, Hejmo T, Poterała-Hejmo A, Leśniak A, Bułdak R. Anti-androgen hormonal therapy for cancer and other diseases. Eur J Pharm. 2020;866:172783 https://doi.org/10.1016/j.ejphar. 2019.172783

9. Gompel A. Hormone and breast cancer. Presse Med. 2019;48:1085-91. https://doi.org/10.1016/j.lpm.2019.09.021

10. Lee YT, Tan YJ, Oon CE. Molecular targeted therapy: treating cancer with specificity. Eur J Pharm. 2018;834:188-96. https:// doi.org/10.1016/j.ejphar.2018.07.034

11. Lev S. Targeted therapy and drug resistance in triple-negative breast cancer: the EGFR axis. Biochem Soc Trans. 2020;48:657-65. https://doi.org/10.1042/bst20191055

12. Guan LY, Lu Y. New developments in molecular targeted therapy of ovarian cancer. Discov Med. 2018;26:219-29.

13. Naik R, Won M, Ban HS, Bhattarai D, Xu X, Eo Y, et al. Synthesis and structure-activity relationship study of chemical probes as hypoxia-induced factor- $1 \alpha /$ malate dehydrogenase 2 inhibitors. J Med Chem. 2014;57:9522-38. https://doi.org/10. $1021 / j m 501241 \mathrm{~g}$

14. O'Neil NJ, Bailey ML, Hieter P. Synthetic lethality and cancer. Nat Rev Genet. 2017;18:613-23. https://doi.org/10.1038/nrg. 2017.47

15. Boccardo F, Amadori D, Guglielmini P, Sismondi P, Farris A, Agostara B, et al. Epirubicin followed by cyclophosphamide, methotrexate and 5-fluorouracil versus paclitaxel followed by epirubicin and vinorelbine in patients with high-risk operable breast cancer. Oncology. 2010;78:274-81. https://doi.org/10. $1159 / 000315735$

16. Abramson JS, Arnason JE, LaCasce AS, Redd R, Barnes JA, Sokol L, et al. Brentuximab vedotin, doxorubicin, vinblastine, and dacarbazine for nonbulky limited-stage classical Hodgkin lymphoma. Blood. 2019;134:606-13. https://doi.org/10.1182/ blood.2019001272

17. Singh S, Gajulapati V, Gajulapati K, Goo J-I, Park Y-H, Jung HY, et al. Structure-activity relationship study of a series of novel oxazolidinone derivatives as IL-6 signaling blockers. Bioorg Medicinal Chem Lett. 2016;26:1282-6. https://doi.org/ 10.1016/j.bmcl.2016.01.016

18. Hong SS, Choi JH, Lee SY, Park YH, Park KY, Lee JY, et al. A novel small-molecule inhibitor targeting the IL-6 receptor $\beta$ subunit, glycoprotein 130. J Immunol. 2015;195:237-45. https:// doi.org/10.4049/jimmunol.1402908

19. Berraondo P, Sanmamed MF, Ochoa MC, Etxeberria I, Aznar MA, Pérez-Gracia JL, et al. Cytokines in clinical cancer immunotherapy. Br J Cancer. 2019;120:6-15. https://doi.org/10.1038/ s41416-018-0328-y

20. Sprooten J, Agostinis P, Garg AD. Type I interferons and dendritic cells in cancer immunotherapy. Int Rev Cell Mol Biol. 2019;348:217-62. https://doi.org/10.1016/bs.ircmb.2019.06.001.j

21. Liang J, Shang Y. Estrogen and cancer. Annu Rev Physiol. 2013;75:225-40. https://doi.org/10.1146/annurev-physiol030212-183708

22. Yassin A, AlRumaihi K, Alzubaidi R, Alkadhi S, Al Ansari A. Testosterone, testosterone therapy and prostate cancer. Aging Male. 2019;22:219-27. https://doi.org/10.1080/13685538.2018. 1524456

23. Drăgănescu M, Carmocan C. Hormone therapy in breast cancer. Chirurgia. 2017;112:413-7. https://doi.org/10.21614/chirurgia. 112.4.413 
24. Lord CJ, Ashworth A. PARP inhibitors: synthetic lethality in the clinic. Science. 2017;355:1152-8. https://doi.org/10.1126/ science.aam7344

25. Mittica G, Ghisoni E, Giannone G, Genta S, Aglietta M, Sapino A, et al. PARP inhibitors in ovarian cancer. Recent Pat Anticancer Drug Discov. 2018;13:392-410. https://doi.org/10.2174/ 1574892813666180305165256

26. Diaby V, Tawk R, Sanogo V, Xiao H, Montero AJ. A review of systematic reviews of the cost-effectiveness of hormone therapy, chemotherapy, and targeted therapy for breast cancer. Breast Cancer Res Treat. 2015;151:27-40. https://doi.org/10.1007/ s10549-015-3383-6

27. Parker C, Lewington V, Shore N, Kratochwil C, Levy M, Lindén $\mathrm{O}$, et al. Targeted alpha therapy, an emerging class of cancer agents: a review. JAMA Oncol. 2018;4:1765-72. https://doi.org/ 10.1001/jamaoncol.2018.4044

28. Vener C, Banzi R, Ambrogi F, Ferrero A, Saglio G, Pravettoni $\mathrm{G}$, et al. First-line imatinib vs second- and third-generation TKIs for chronic-phase CML: a systematic review and meta-analysis. Blood Adv. 2020;4:2723-35. https://doi.org/10.1182/bloodadva nces.2019001329

29. Noronha V, Patil VM, Joshi A, Menon N, Chougule A, Mahajan A, et al. Gefitinib versus gefitinib plus pemetrexed and carboplatin chemotherapy in EGFR-mutated lung cancer. J Clin Oncol. 2020;38:124-36. https://doi.org/10.1200/jco.19.01154

30. Cheson BD, Chua N, Mayer J, Dueck G, Trněný M, Bouabdallah $\mathrm{K}$, et al. Overall survival benefit in patients with rituximabrefractory indolent non-hodgkin lymphoma who received obinutuzumab plus bendamustine induction and obinutuzumab maintenance in the GADOLIN study. J Clin Oncol. 2018;36:2259-66. https://doi.org/10.1200/jco.2017.76.3656

31. Chao MP, Alizadeh AA, Tang C, Myklebust JH, Varghese B, Gill S, et al. Anti-CD47 antibody synergizes with rituximab to promote phagocytosis and eradicate non-Hodgkin lymphoma. Cell. 2010;142:699-713. https://doi.org/10.1016/j.cell.2010.07. 044

32. Lee S, Lee H, Kim E. Comparative efficacy and safety of biosimilar rituximab and originator rituximab in rheumatoid arthritis and non-Hodgkin's lymphoma: a systematic review and metaanalysis. BioDrugs. 2019;33:469-83. https://doi.org/10.1007/ s40259-019-00376-Z

33. Taylor SS, Kornev AP. Protein kinases: evolution of dynamic regulatory proteins. Trends Biochem Sci. 2011;36:65-77. https:// doi.org/10.1016/j.tibs.2010.09.006

34. Johnson GL, Lapadat R. Mitogen-activated protein kinase pathways mediated by ERK, JNK, and p38 protein kinases. Science. 2002;298:1911-2. https://doi.org/10.1126/science. 1072682

35. Sirotkin AV, Makarevich AV, Grosmann R. Protein kinases and ovarian functions. J Cell Physiol. 2011;226:37-45. https://doi. org/10.1002/jcp. 22364

36. Goldsmith EJ, Cobb MH. Protein kinases. Curr Opin Struct Biol. 1994;4:833-40. https://doi.org/10.1016/0959-440x(94)90264-x

37. Roskoski R Jr. Properties of FDA-approved small molecule protein kinase inhibitors: a 2021 update. Pharm Res. 2021;165:105463 https://doi.org/10.1016/j.phrs.2021.105463

38. Löcken H, Clamor C, Müller K. Napabucasin and related heterocycle-fused naphthoquinones as STAT3 inhibitors with antiproliferative activity against cancer cells. J Nat Prod. 2018;81:1636-44. https://doi.org/10.1021/acs.jnatprod.8b00247

39. Pawar S, Kumar K, Gupta MK, Rawal RK. Synthetic and medicinal perspective of fused-thiazoles as anticancer agents. Anticancer Agents Med Chem. 2020. https://doi.org/10.2174/ 1871520620666200728133017.

40. Zhou J, Liao B, Deng Y, Guo X, Zhao J, Sun J. et al.Design and synthesis of imidazo-fused heterocycles derivatives and their anti-tumor activity against breast cancer in mice.Nan Fang Yi Ke Da Xue Xue Bao. 2018;38:1052-60. https://doi.org/10.12122/j. issn.1673-4254.2018.09.05.

41. Mohareb RM, Milad YR, El-Ansary RA. New Approaches for the synthesis of fused thiophene, pyrazole, pyran and pyridine derivatives with anti-proliferative together with c-Met kinase and prostate cancer cell inhibitions. Anticancer Agents Med Chem. 2020. https://doi.org/10.2174/1871520620999201110191056.

42. Singh S, Goo J, Gajulapati V, Chang TS, Lee K, Choi Y. Recent advances in anticancer chemotherapeutics based upon azepine scaffold. Anticancer Agents Med Chem. 2016;16:539-57. https://doi.org/10.2174/1871520615666150916091750

43. Singh S, Veeraswamy G, Bhattarai D, Goo J-I, Lee K, Choi Y. Recent advances in the development of pharmacologically active compounds that contain a benzoxazole scaffold. Asian J Org Chem. 2015;4:1338-61. https://doi.org/10.1002/ajoc.201500235

44. Ott GR, Favor DA. Pyrrolo[2,1-f][1,2,4]triazines: from $\mathrm{C}$-nucleosides to kinases and back again, the remarkable journey of a versatile nitrogen heterocycle. Bioorg Med Chem Lett. 2017;27:4238-46. https://doi.org/10.1016/j.bmcl.2017.07.073

45. Dhillon S. Avapritinib: first approval. Drugs. 2020;80:433-9. https://doi.org/10.1007/s40265-020-01275-2

46. Sarbjit S, Deepak B, Gajulapati V, Yongseok C, Kyeong L. Nucleosides with modified sugar ring: synthesis and biological activities. Curr Org Chem. 2016;20:856-97. https://doi.org/10. 2174/1385272819666150803235458

47. Singh S, Gajulapati V, Kim M, Goo J-I, Lee JK, Lee K, et al. A divergent approach for the synthesis of D- and L-4'-ethynyl dioxolane nucleosides with potent anti-HIV activity. Synthesis 2016;48:3050-6.

48. Rai GS, Maru JJ. Synthetic strategies for pyrrolo[2,1-f][1,2,4] triazine: the parent moiety of antiviral drug remdesivir. Chem Heterocycl Compd. 2021:1-6. https://doi.org/10.1007/s10593020-02844-9.

49. Abbaspour Babaei M, Kamalidehghan B, Saleem M, Huri HZ, Ahmadipour F. Receptor tyrosine kinase (c-Kit) inhibitors: a potential therapeutic target in cancer cells. Drug Des Devel Ther. 2016;10:2443-59. https://doi.org/10.2147/dddt.S89114

50. Jiao Q, Bi L, Ren Y, Song S, Wang Q, Wang YS. Advances in studies of tyrosine kinase inhibitors and their acquired resistance. Mol Cancer. 2018;17:36 https://doi.org/10.1186/s12943-0180801-5

51. Huang L, Jiang S, Shi Y. Tyrosine kinase inhibitors for solid tumors in the past 20 years (2001-2020). J Hematol Oncol. 2020;13:143 https://doi.org/10.1186/s13045-020-00977-0

52. Rajaram P, Chandra P, Ticku S, Pallavi BK, Rudresh KB, Mansabdar P. Epidermal growth factor receptor: Role in human cancer. Indian J Dent Res. 2017;28:687-94. https://doi.org/10. 4103/ijdr.IJDR_534_16

53. Roskoski R Jr. Small molecule inhibitors targeting the EGFR/ ErbB family of protein-tyrosine kinases in human cancers. Pharm Res. 2019;139:395-411. https://doi.org/10.1016/j.phrs.2018.11. 014

54. Singh D, Attri BK, Gill RK, Bariwal J. Review on EGFR inhibitors: critical updates. Mini Rev Med Chem. 2016;16:1134-66. https://doi.org/10.2174/1389557516666160321114917

55. Yang Z, Hackshaw A, Feng Q, Fu X, Zhang Y, Mao C, et al. Comparison of gefitinib, erlotinib and afatinib in non-small cell lung cancer: a meta-analysis. Int J Cancer. 2017;140:2805-19. https://doi.org/10.1002/ijc.30691

56. Kim Y, Lee SH, Ahn JS, Ahn MJ, Park K, Sun JM. Efficacy and safety of afatinib for EGFR-mutant non-small cell lung cancer, compared with gefitinib or erlotinib. Cancer Res Treat. 2019;51:502-9. https://doi.org/10.4143/crt.2018.117

57. Carmeliet P. VEGF as a key mediator of angiogenesis in cancer. Oncology. 2005;69:4-10. https://doi.org/10.1159/000088478 
58. Botelho F, Pina F, Lunet N. VEGF and prostatic cancer: a systematic review. Eur J Cancer Prev. 2010;19:385-92. https://doi. org/10.1097/CEJ.0b013e32833b48e1

59. Paik ES, Kim TH, Cho YJ, Ryu J, Choi JJ, Lee YY, et al. Preclinical assessment of the VEGFR inhibitor axitinib as a therapeutic agent for epithelial ovarian cancer. Sci Rep. 2020;10:4904 https://doi.org/10.1038/s41598-020-61871-w

60. Abou-Alfa GK, Meyer T, Cheng AL, El-Khoueiry AB, Rimassa $\mathrm{L}$, Ryoo BY, et al. Cabozantinib in patients with advanced and progressing hepatocellular carcinoma. $\mathrm{N}$ Engl $\mathrm{J}$ Med. 2018;379:54-63. https://doi.org/10.1056/NEJMoa1717002

61. Zhu C, Ma X, Hu Y, Guo L, Chen B, Shen K, et al. Safety and efficacy profile of lenvatinib in cancer therapy: a systematic review and meta-analysis. Oncotarget. 2016;7:44545-57. https:// doi.org/10.18632/oncotarget.10019

62. Chellappan DK, Chellian J, Ng ZY, Sim YJ, Theng CW, Ling J, et al. The role of pazopanib on tumour angiogenesis and in the management of cancers: a review. Biomed Pharmacother. 2017;96:768-81. https://doi.org/10.1016/j.biopha.2017.10.058

63. Abrahao ABK, Ko YJ, Berry S, Chan KKW. A comparison of regorafenib and TAS-102 for metastatic colorectal cancer: a systematic review and network meta-analysis. Clin Colorectal Cancer. 2018;17:113-20. https://doi.org/10.1016/j.clcc.2017.10.016

64. Mangana J, Levesque MP, Karpova MB, Dummer R. Sorafenib in melanoma. Expert Opin Investig Drugs. 2012;21:557-68. https://doi.org/10.1517/13543784.2012.665872

65. Buonerba C, Dolce P, Iaccarino S, Scafuri L, Verde A, Costabile $\mathrm{F}$, et al. Outcomes associated with first-line anti-PD-1/ PD-L1 agents vs. sunitinib in patients with sarcomatoid renal cell carcinoma: a systematic review and meta-analysis. Cancers. 2020;12. https://doi.org/10.3390/cancers 12020408 .

66. Wells SA Jr, Robinson BG, Gagel RF, Dralle H, Fagin JA, Santoro M, et al. Vandetanib in patients with locally advanced or metastatic medullary thyroid cancer: a randomized, double-blind phase III trial. J Clin Oncol. 2012;30:134-41. https://doi.org/10. 1200/jco.2011.35.5040

67. Roskoski R Jr. Properties of FDA-approved small molecule protein kinase inhibitors: a 2020 update. Pharm Res. 2020;152:104609 https://doi.org/10.1016/j.phrs.2019.104609

68. Hunt JT, Mitt T, Borzilleri R, Gullo-Brown J, Fargnoli J, Fink B, et al. Discovery of the pyrrolo[2,1-f][1,2,4]triazine nucleus as a new kinase inhibitor template. J Med Chem. 2004;47:4054-9. https://doi.org/10.1021/jm049892u

69. Borzilleri RM, Cai ZW, Ellis C, Fargnoli J, Fura A, Gerhardt T, et al. Synthesis and SAR of 4-(3-hydroxyphenylamino)pyrrolo[2,1f] $[1,2,4]$ triazine based VEGFR-2 kinase inhibitors. Bioorg Med Chem Lett. 2005;15:1429-33. https://doi.org/10.1016/j.bmcl.2004. 12.079

70. Dai S, Zhou Z, Chen Z, Xu G, Chen Y. Fibroblast growth factor receptors (FGFRs): structures and small molecule inhibitors. Cells. 2019;8. https://doi.org/10.3390/cells8060614.

71. Babina IS, Turner NC. Advances and challenges in targeting FGFR signalling in cancer. Nat Rev Cancer. 2017;17:318-32. https://doi.org/10.1038/nrc.2017.8

72. Montazeri K, Bellmunt J. Erdafitinib for the treatment of metastatic bladder cancer. Expert Rev Clin Pharm. 2020;13:1-6. https://doi.org/10.1080/17512433.2020.1702025

73. Marandino L, Raggi D, Giannatempo P, Farè E, Necchi A. Erdafitinib for the treatment of urothelial cancer. Expert Rev Anticancer Ther. 2019;19:835-46. https://doi.org/10.1080/14737140.2019. 1671190

74. Wind S, Schmid U, Freiwald M, Marzin K, Lotz R, Ebner T, et al. Clinical pharmacokinetics and pharmacodynamics of nintedanib. Clin Pharmacokinet. 2019;58:1131-47. https://doi.org/ 10.1007/s40262-019-00766-0
75. Borzilleri RM, Zheng X, Qian L, Ellis C, Cai ZW, Wautlet BS, et al. Design, synthesis, and evaluation of orally active 4-(2,4difluoro-5-(methoxycarbamoyl)phenylamino)pyrrolo[2,1-f]

$[1,2,4]$ triazines as dual vascular endothelial growth factor receptor-2 and fibroblast growth factor receptor-1 inhibitors. J Med Chem. 2005;48:3991-4008. https://doi.org/10.1021/ jm0501275

76. Fink BE, Vite GD, Mastalerz H, Kadow JF, Kim SH, Leavitt KJ, et al. New dual inhibitors of EGFR and HER2 protein tyrosine kinases. Bioorg Med Chem Lett. 2005;15:4774-9. https://doi. org/10.1016/j.bmcl.2005.07.027

77. Mastalerz H, Gavai AV, Fink B, Struzynski C, Tarrant J, Vite GD, et al. Pyrrolotriazine-5-carboxylate ester inhibitors of EGFR and HER2 protein tyrosine kinases and a novel one-pot synthesis of C-4 subsitituted pyrrole-2,3-dicarboxylate diesters. Can J Chem. 2006;84:528-33. https://doi.org/10.1139/v06-037

78. Mastalerz H, Chang M, Chen P, Dextraze P, Fink BE, Gavai A, et al. New C-5 substituted pyrrolotriazine dual inhibitors of EGFR and HER2 protein tyrosine kinases. Bioorg Med Chem Lett. 2007;17:2036-42. https://doi.org/10.1016/j.bmcl.2007.01.002

79. Mastalerz H, Chang M, Gavai A, Johnson W, Langley D, Lee FY, et al. Novel C-5 aminomethyl pyrrolotriazine dual inhibitors of EGFR and HER2 protein tyrosine kinases. Bioorg Med Chem Lett. 2007;17:2828-33. https://doi.org/10.1016/j.bmcl.2007.02. 050

80. Mastalerz H, Chang M, Chen P, Fink BE, Gavai A, Han WC, et al. 5-((4-Aminopiperidin-1-yl)methyl)pyrrolotriazine dual inhibitors of EGFR and HER2 protein tyrosine kinases. Bioorg Med Chem Lett. 2007;17:4947-54. https://doi.org/10.1016/j. bmcl.2007.06.019

81. Fink BE, Norris D, Mastalerz H, Chen P, Goyal B, Zhao Y, et al. Novel pyrrolo[2,1-f][1,2,4]triazin-4-amines: dual inhibitors of EGFR and HER2 protein tyrosine kinases. Bioorg Med Chem Lett. 2011;21:781-5. https://doi.org/10.1016/j.bmcl.2010.11.100

82. Wong TW, Lee FY, Yu C, Luo FR, Oppenheimer S, Zhang H, et al. Preclinical antitumor activity of BMS-599626, a pan-HER kinase inhibitor that inhibits HER1/HER2 homodimer and heterodimer signaling. Clin Cancer Res. 2006;12:6186-93. https:// doi.org/10.1158/1078-0432.Ccr-06-0642

83. Cai ZW, Wei D, Borzilleri RM, Qian L, Kamath A, Mortillo S. et al. Synthesis, SAR, and evaluation of 4-[2,4-difluoro-5(cyclopropylcarbamoyl)phenylamino]pyrrolo[2,1-f][1,2,4]triazine-based VEGFR-2 kinase inhibitors. Bioorg Med Chem Lett. 2008;18:1354-8. https://doi.org/10.1016/j.bmcl.2008.01.012.

84. Fioroni I, Dell'Aquila E, Pantano F, Intagliata S, Caricato M, Vincenzi B, et al. Role of c-mesenchymal-epithelial transition pathway in gastric cancer. Expert Opin Pharmacother. 2015;16:1195-207. https://doi.org/10.1517/14656566.2015. 1037739

85. Pasquini G, Giaccone G. C-MET inhibitors for advanced non-small cell lung cancer. Expert Opin Investig Drugs. 2018;27:363-75. https://doi.org/10.1080/13543784.2018.1462336

86. Dhillon S. Capmatinib: first approval. Drugs. 2020;80:1125-31. https://doi.org/10.1007/s40265-020-01347-3

87. Shi W, Qiang H, Huang D, Bi X, Huang W, Qian H. Exploration of novel pyrrolo[2,1-f][1,2,4]triazine derivatives with improved anticancer efficacy as dual inhibitors of c-Met/VEGFR-2. Eur J Med Chem. 2018;158:814-31. https://doi.org/10.1016/j.ejmech. 2018.09.050

88. Schroeder GM, Chen XT, Williams DK, Nirschl DS, Cai ZW, Wei D, et al. Identification of pyrrolo[2,1-f][1,2,4]triazine-based inhibitors of Met kinase. Bioorg Med Chem Lett. 2008;18:1945-51. https://doi.org/10.1016/j.bmcl.2008.01.121

89. Kong X, Pan P, Sun H, Xia H, Wang X, Li Y, et al. Drug discovery targeting anaplastic lymphoma kinase (ALK). J Med 
Chem. 2019;62:10927-54. https://doi.org/10.1021/acs. jmedchem.9b00446

90. Umapathy G, Mendoza-Garcia P, Hallberg B, Palmer RH. Targeting anaplastic lymphoma kinase in neuroblastoma. Apmis. 2019;127:288-302. https://doi.org/10.1111/apm.12940

91. Golding B, Luu A, Jones R, Viloria-Petit AM. The function and therapeutic targeting of anaplastic lymphoma kinase (ALK) in non-small cell lung cancer (NSCLC). Mol Cancer. 2018;17:52 https://doi.org/10.1186/s12943-018-0810-4

92. van Gaal JC, Roeffen MH, Flucke UE, van der Laak JA, van der Heijden G, de Bont ES, et al. Simultaneous targeting of insulinlike growth factor-1 receptor and anaplastic lymphoma kinase in embryonal and alveolar rhabdomyosarcoma: a rational choice. Eur J Cancer. 2013;49:3462-70. https://doi.org/10.1016/j.ejca. 2013.06.022

93. Ott GR, Wells GJ, Thieu TV, Quail MR, Lisko JG, Mesaros EF, et al. 2,7-disubstituted-pyrrolo[2,1-f][1,2,4]triazines: new variant of an old template and application to the discovery of anaplastic lymphoma kinase (ALK) inhibitors with in vivo antitumor activity. J Med Chem. 2011;54:6328-41. https://doi.org/10. 1021/jm200758k

94. Mesaros EF, Thieu TV, Wells GJ, Zificsak CA, Wagner JC, Breslin $\mathrm{HJ}$, et al. Strategies to mitigate the bioactivation of 2anilino-7-aryl-pyrrolo[2,1-f][1,2,4]triazines: identification of orally bioavailable, efficacious ALK inhibitors. J Med Chem. 2012;55:115-25. https://doi.org/10.1021/jm2010767

95. Mesaros EF, Angeles TS, Albom MS, Wagner JC, Aimone LD, Wan W, et al. Piperidine-3,4-diol and piperidine-3-ol derivatives of pyrrolo[2,1-f][1,2,4]triazine as inhibitors of anaplastic lymphoma kinase. Bioorg Med Chem Lett. 2015;25:1047-52. https://doi.org/10.1016/j.bmcl.2015.01.019

96. Slater T, Haywood NJ, Matthews C, Cheema H, Wheatcroft SB. Insulin-like growth factor binding proteins and angiogenesis: from cancer to cardiovascular disease. Cytokine Growth Factor Rev. 2019;46:28-35. https://doi.org/10.1016/j.cytogfr.2019.03. 005

97. Wang Z, Li W, Guo Q, Wang Y, Ma L, Zhang X. Insulin-like growth factor-1 signaling in lung development and inflammatory lung diseases. Biomed Res Int. 2018;2018:6057589 https://doi. org/10.1155/2018/6057589

98. Fettig LM, Yee D. Advances in insulin-like growth factor biology and -directed cancer therapeutics. Adv Cancer Res. 2020;147:229-57. https://doi.org/10.1016/bs.acr.2020.04.005

99. Chen HX, Sharon E. IGF-1R as an anti-cancer target-trials and tribulations. Chin J Cancer. 2013;32:242-52. https://doi.org/10. 5732/cjc.012.10263

100. Gong H, Wang X, Wang L, Liu Y, Wang J, Lv Q, et al. Inhibition of IGF-1 receptor kinase blocks the differentiation into cardiomyocyte-like cells of BMSCs induced by IGF-1. Mol Med Rep. 2017;16:787-93. https://doi.org/10.3892/mmr. 2017.6639

101. Tang Q, Ma J, Sun J, Yang L, Yang F, Zhang W, et al. Genistein and AG1024 synergistically increase the radiosensitivity of prostate cancer cells. Oncol Rep. 2018;40:579-88. https://doi. org/10.3892/or.2018.6468

102. Wu W, Ma J, Shao N, Shi Y, Liu R, Li W, et al. Co-targeting IGF-1R and autophagy enhances the effects of cell growth suppression and apoptosis induced by the IGF-1R inhibitor NVP-AEW541 in triple-negative breast cancer cells. PLoS One. 2017;12:e0169229 https://doi.org/10.1371/journal.pone.0169229

103. Wittman MD, Carboni JM, Yang Z, Lee FY, Antman M, Attar $\mathrm{R}$, et al. Discovery of a 2,4-disubstituted pyrrolo[1,2-f][1,2,4] triazine inhibitor (BMS-754807) of insulin-like growth factor receptor (IGF-1R) kinase in clinical development. J Med Chem. 2009;52:7360-3. https://doi.org/10.1021/jm900786r
104. Roskoski R Jr. Janus kinase (JAK) inhibitors in the treatment of inflammatory and neoplastic diseases. Pharm Res. 2016;111:784-803. https://doi.org/10.1016/j.phrs.2016.07.038

105. Clark JD, Flanagan ME, Telliez JB. Discovery and development of Janus kinase (JAK) inhibitors for inflammatory diseases. J Med Chem. 2014;57:5023-38. https://doi.org/10.1021/jm401490p

106. Taylor PC, Keystone EC, van der Heijde D, Weinblatt ME, Del Carmen Morales L, Reyes Gonzaga J, et al. Baricitinib versus placebo or adalimumab in rheumatoid arthritis. N Engl J Med. 2017;376:652-62. https://doi.org/10.1056/NEJMoa1608345

107. Pardanani A, Harrison C, Cortes JE, Cervantes F, Mesa RA, Milligan D, et al. Safety and efficacy of fedratinib in patients with primary or secondary myelofibrosis: a randomized clinical trial. JAMA Oncol. 2015;1:643-51. https://doi.org/10.1001/jama oncol.2015.1590

108. Wollenhaupt J, Lee EB, Curtis JR, Silverfield J, Terry K, Soma $\mathrm{K}$, et al. Safety and efficacy of tofacitinib for up to 9.5 years in the treatment of rheumatoid arthritis: final results of a global, open-label, long-term extension study. Arthritis Res Ther. 2019;21:89 https://doi.org/10.1186/s13075-019-1866-2

109. Harikrishnan LS, Kamau MG, Wan H, Inghrim JA, Zimmermann K, Sang X, et al. Pyrrolo[1,2-f]triazines as JAK2 inhibitors: achieving potency and selectivity for JAK2 over JAK3. Bioorg Med Chem Lett. 2011;21:1425-8. https://doi.org/10. 1016/j.bmcl.2011.01.022

110. Wells-Knecht KJ, Ott GR, Cheng M, Wells GJ, Breslin HJ, Gingrich DE, et al. 2,7-Disubstituted-pyrrolotriazine kinase inhibitors with an unusually high degree of reactive metabolite formation. Chem Res Toxicol. 2011;24:1994-2003. https://doi. org/10.1021/tx200304r

111. Weinberg LR, Albom MS, Angeles TS, Breslin HJ, Gingrich DE, Huang $Z$, et al. 2,7-Pyrrolo[2,1-f][1,2,4]triazines as JAK2 inhibitors: modification of target structure to minimize reactive metabolite formation. Bioorg Med Chem Lett. 2011;21:7325-30. https://doi.org/10.1016/j.bmcl.2011.10.032

112. Tang A, Gao K, Chu L, Zhang R, Yang J, Zheng J. Aurora kinases: novel therapy targets in cancers. Oncotarget. 2017;8:23937-54. https://doi.org/10.18632/oncotarget.14893

113. Bolanos-Garcia VM. Aurora kinases. Int J Biochem Cell Biol. 2005;37:1572-7. https://doi.org/10.1016/j.biocel.2005.02.021

114. Lee HA, Kwon M, Kim HA, Kim KS. Antitumor profiles and cardiac electrophysiological effects of aurora kinase inhibitor ZM447439. Korean J Physiol Pharm. 2019;23:393-402. https:// doi.org/10.4196/kjpp.2019.23.5.393

115. Morahan BJ, Abrie C, Al-Hasani K, Batty MB, Corey V, Cowell AN, et al. Human Aurora kinase inhibitor Hesperadin reveals epistatic interaction between Plasmodium falciparum PfArk1 and PfNek1 kinases. Commun Biol. 2020;3:701 https://doi.org/10. 1038/s42003-020-01424-Z

116. Zhang LN, Ji K, Sun YT, Hou YB, Chen JJ. Aurora kinase inhibitor tozasertib suppresses mast cell activation in vitro and in vivo. Br J Pharm. 2020;177:2848-59. https://doi.org/10.1111/ bph. 15012

117. Abraham S, Hadd MJ, Tran L, Vickers T, Sindac J, Milanov ZV, et al. Novel series of pyrrolotriazine analogs as highly potent pan-Aurora kinase inhibitors. Bioorg Med Chem Lett. 2011;21:5296-300. https://doi.org/10.1016/j.bmcl.2011.07.027

118. Liu G, Abraham S, Tran L, Vickers TD, Xu S, Hadd MJ, et al. Discovery of highly potent and selective pan-Aurora kinase inhibitors with enhanced in vivo antitumor therapeutic index. $\mathrm{J}$ Med Chem. 2012;55:3250-60. https://doi.org/10.1021/ jm201702g

119. Chuang HC, Wang X, Tan TH. MAP4K family kinases in immunity and inflammation. Adv Immunol. 2016;129:277-314. https://doi.org/10.1016/bs.ai.2015.09.006 
120. Gao X, Gao C, Liu G, Hu J. MAP4K4: an emerging therapeutic target in cancer. Cell Biosci. 2016;6:56 https://doi.org/10.1186/ s13578-016-0121-7

121. Wang L, Stanley M, Boggs JW, Crawford TD, Bravo BJ, Giannetti AM, et al. Fragment-based identification and optimization of a class of potent pyrrolo[2,1-f][1,2,4]triazine MAP4K4 inhibitors. Bioorg Med Chem Lett. 2014;24:4546-52. https://doi. org/10.1016/j.bmcl.2014.07.071

122. Fruman DA, Chiu H, Hopkins BD, Bagrodia S, Cantley LC, Abraham RT. The PI3K pathway in human disease. Cell. 2017;170:605-35. https://doi.org/10.1016/j.cell.2017.07.029

123. Fresno Vara JA, Casado E, de Castro J, Cejas P, Belda-Iniesta C, González-Barón M. PI3K/Akt signalling pathway and cancer. Cancer Treat Rev. 2004;30:193-204. https://doi.org/10.1016/j. ctrv.2003.07.007

124. Martini M, De Santis MC, Braccini L, Gulluni F, Hirsch E. PI3K/AKT signaling pathway and cancer: an updated review. Ann Med. 2014;46:372-83. https://doi.org/10.3109/07853890. 2014.912836

125. Markham A. Idelalisib: first global approval. Drugs. 2014;74:1701-7. https://doi.org/10.1007/s40265-014-0285-6

126. Markham A. Copanlisib: first global approval. Drugs. 2017;77:2057-62. https://doi.org/10.1007/s40265-017-0838-6

127. Blair HA. Duvelisib: first global approval. Drugs. 2018;78:1847-53. https://doi.org/10.1007/s40265-018-1013-4

128. Dugar S, Hollinger FP, Kuila B, Arora R, Sen S, Mahajan D. Synthesis and evaluation of pyrrolotriazine based molecules as PI3 kinase inhibitors. Bioorg Med Chem Lett. 2015;25:3142-6. https://doi.org/10.1016/j.bmcl.2015.06.007

129. Erra M, Taltavull J, Gréco A, Bernal FJ, Caturla JF, Gràcia J, et al. Discovery of a potent, selective, and orally available PI3K $\delta$ inhibitor for the treatment of inflammatory diseases. ACS Med Chem Lett. 2017;8:118-23. https://doi.org/10.1021/acsmedchemlett.6b00438

130. Bhide RS, Neels J, Qin LY, Ruan Z, Stachura S, Weigelt C, et al. Discovery and SAR of pyrrolo[2,1-f][1,2,4]triazin-4-amines as potent and selective PI3K $\delta$ inhibitors. Bioorg Med Chem Lett. 2016;26:4256-60. https://doi.org/10.1016/j.bmcl.2016.07.047

131. Qin LY, Ruan Z, Cherney RJ, Dhar TGM, Neels J, Weigelt CA, et al. Discovery of 7-(3-(piperazin-1-yl)phenyl)pyrrolo[2,1-f] $[1,2,4]$ triazin-4-amine derivatives as highly potent and selective PI3KS inhibitors. Bioorg Med Chem Lett. 2017;27:855-61. https://doi.org/10.1016/j.bmcl.2017.01.016

132. Marcoux D, Qin LY, Ruan Z, Shi Q, Ruan Q, Weigelt C, et al. Identification of highly potent and selective PI3K $\delta$ inhibitors. Bioorg Med Chem Lett. 2017;27:2849-53. https://doi.org/10. 1016/j.bmcl.2017.01.077

133. Xiang HY, Chen YH, Wang Y, Zhang X, Ding J, Meng LH, et al. Design, synthesis and antiproliferative activity evaluation of a series of pyrrolo[2,1-f][1,2,4]triazine derivatives. Bioorg Med Chem Lett. 2020;30:127194 https://doi.org/10.1016/j.bmcl. 2020.127194

134. Jia H, Dai G, Su W, Xiao K, Weng J, Zhang Z, et al. Discovery, optimization, and evaluation of potent and highly selective PI3K $\gamma$-PI3K $\delta$ dual inhibitors. J Med Chem. 2019;62:4936-48. https://doi.org/10.1021/acs.jmedchem.8b02014

135. McElroy WT. Interleukin-1 receptor-associated kinase 4 (IRAK4) inhibitors: an updated patent review (2016-2018). Expert Opin Ther Pat. 2019;29:243-59. https://doi.org/10.1080/ 13543776.2019.1597850

136. Genung NE, Guckian KM. Small molecule inhibition of interleukin-1 receptor-associated kinase 4 (IRAK4). Prog Med Chem. 2017;56:117-63. https://doi.org/10.1016/bs.pmch.2016. 11.004

137. Gummadi VR, Boruah A, Ainan BR, Vare BR, Manda S, Gondle HP, et al. Discovery of CA-4948, an orally bioavailable IRAK4 inhibitor for treatment of hematologic malignancies. ACS Med
Chem Lett. 2020;11:2374-81. https://doi.org/10.1021/a csmedchemlett.0c00255

138. Degorce SL, Anjum R, Dillman KS, Drew L, Groombridge SD, Halsall CT, et al. Optimization of permeability in a series of pyrrolotriazine inhibitors of IRAK4. Bioorg Med Chem. 2018;26:913-24. https://doi.org/10.1016/j.bmc.2018.01.008

139. Skoda AM, Simovic D, Karin V, Kardum V, Vranic S, Serman L. The role of the Hedgehog signaling pathway in cancer: a comprehensive review. Bosn J Basic Med Sci. 2018;18:8-20. https://doi.org/10.17305/bjbms.2018.2756

140. Zeng X, Ju D. Hedgehog signaling pathway and autophagy in cancer. Int J Mol Sci. 2018;19. https://doi.org/10.3390/ ijms 19082279 .

141. Quaglio D, Infante P, Di Marcotullio L, Botta B, Mori M. Hedgehog signaling pathway inhibitors: an updated patent review (2015-present). Expert Opin Ther Pat. 2020;30:235-50. https://doi.org/10.1080/13543776.2020.1730327

142. Wahid M, Jawed A, Mandal RK, Dar SA, Khan S, Akhter N, et al. Vismodegib, itraconazole and sonidegib as hedgehog pathway inhibitors and their relative competencies in the treatment of basal cell carcinomas. Crit Rev Oncol Hematol. 2016;98:235-41. https://doi.org/10.1016/j.critrevonc.2015.11. 006

143. Xin M, Zhang L, Tang F, Tu C, Wen J, Zhao X, et al. Design, synthesis, and evaluation of pyrrolo[2,1-f][1,2,4]triazine derivatives as novel hedgehog signaling pathway inhibitors. Bioorg Med Chem. 2014;22:1429-40. https://doi.org/10.1016/j.bmc. 2013.12.055

144. Kim KS, Lu S, Cornelius LA, Lombardo LJ, Borzilleri RM, Schroeder GM, et al. Synthesis and SAR of pyrrolotriazine-4-one based Eg5 inhibitors. Bioorg Med Chem Lett. 2006;16:3937-42. https://doi.org/10.1016/j.bmcl.2006.05.037

145. Hu C, Dong X. Cysteine-targeted irreversible inhibitors of tyrosine kinases and key interactions. Curr Med Chem. 2019;26:5811-24. 0929867325666180713124223

146. Bernetti M, Masetti M, Rocchia W, Cavalli A. Kinetics of Drug Binding and Residence Time. Annu Rev Phys Chem. 2019;70:143-71. https://doi.org/10.1146/annurev-physchem042018-052340

147. Piesche M, Roos J, Kühn B, Fettel J, Hellmuth N, Brat C, et al. The emerging therapeutic potential of nitro fatty acids and other michael acceptor-containing drugs for the treatment of inflammation and cancer. Front Pharm. 2020;11:1297 https://doi.org/ 10.3389/fphar.2020.01297

148. Benowitz AB, Jones KL, Harling JD. The therapeutic potential of PROTACs. Expert Opin Ther Pat. 2021;31:1-24. https://doi. org/10.1080/13543776.2021.1840553

149. Baek K, Schulman BA. Molecular glue concept solidifies. Nat Chem Biol. 2020;16:2-3. https://doi.org/10.1038/s41589-0190414-3

150. Girardini M, Maniaci C, Hughes SJ, Testa A, Ciulli A. Cereblon versus VHL: hijacking E3 ligases against each other using PROTACs. Bioorg Med Chem. 2019;27:2466-79. https://doi. org/10.1016/j.bmc.2019.02.048

151. Lim J, Altman MD, Baker J, Brubaker JD, Chen H, Chen Y, et al. Identification of $\mathrm{N}-(1 \mathrm{H}-$ pyrazol-4-yl)carboxamide inhibitors of interleukin-1 receptor associated kinase 4: bicyclic core modifications. Bioorg Med Chem Lett. 2015;25:5384-8. https:// doi.org/10.1016/j.bmcl.2015.09.028

152. Johannes JW, Almeida L, Barlaam B, Boriack-Sjodin PA, Casella R, Croft RA, et al. Pyrimidinone nicotinamide mimetics as selective tankyrase and wnt pathway inhibitors suitable for in vivo pharmacology. ACS Med Chem Lett. 2015;6:254-9. https://doi.org/10.1021/ml5003663 
153. Holmes JL, Almeida L, Barlaam B, Croft RA, Dishington AP, Gingipalli L, et al. Synthesis of novel hydroxymethyl-substituted fused heterocycles. Synthesis 2016;48:1226-34.

154. Thieu T, Sclafani JA, Levy DV, McLean A, Breslin HJ, Ott GR, et al. Discovery and process synthesis of novel 2,7-pyrrolo[2,1-f] [1,2,4]triazines. Org Lett. 2011;13:4204-7. https://doi.org/10. $1021 /$ ol2015237

155. Quintela J, Moreira MJ, Peinador C. A ready one-pot preparation for pyrrolo[2,1-f]-[1,2,4]triazine and pyrazolo[5,1-c]pyrimido[4,5e]-[1,2,4]triazine derivatives. Tetrahedron. 1996;52:3037-48. https://doi.org/10.1016/0040-4020(95)01121-8

156. Amit S, Sarbjit S, Divya U. Recent advances in synthesis and antifungal activity of 1,3,5-triazines. Curr Org Synth. 2016;13:484-503. https://doi.org/10.2174/15701794126661509050 02356

157. Chong QY, Kok ZH, Bui NL, Xiang X, Wong AL, Yong WP, et al. A unique CDK4/6 inhibitor: current and future therapeutic strategies of abemaciclib. Pharm Res. 2020;156:104686 https:// doi.org/10.1016/j.phrs.2020.104686

158. Wu J, Zhang M, Liu D. Acalabrutinib (ACP-196): a selective second-generation BTK inhibitor. J Hematol Oncol. 2016;9:21 https://doi.org/10.1186/s13045-016-0250-9

159. Wecker H, Waller CF. Afatinib. Recent Results Cancer Res. 2018;211:199-215. https://doi.org/10.1007/978-3-319-91442-8_14

160. Giddabasappa A, Lalwani K, Norberg R, Gukasyan HJ, Paterson D, Schachar RA, et al. Axitinib inhibits retinal and choroidal neovascularization in in vitro and in vivo models. Exp Eye Res. 2016;145:373-9. https://doi.org/10.1016/j.exer.2016.02.010

161. Nezamololama N, Fieldhouse K, Metzger K, Gooderham M. Emerging systemic JAK inhibitors in the treatment of atopic dermatitis: a review of abrocitinib, baricitinib, and upadacitinib. Drugs Context. 2020;9. https://doi.org/10.7573/dic.2020-8-5.

162. Tran B, Cohen MS. The discovery and development of binimetinib for the treatment of melanoma. Expert Opin Drug Discov. 2020;15:745-54. https://doi.org/10.1080/17460441.2020.1746265

163. Wu YL, Cheng Y, Zhou X, Lee KH, Nakagawa K, Niho S, et al. Dacomitinib versus gefitinib as first-line treatment for patients with EGFR-mutation-positive non-small-cell lung cancer (ARCHER 1050): a randomised, open-label, phase 3 trial. Lancet Oncol. 2017;18:1454-66. https://doi.org/10.1016/s1470-2045 (17)30608-3

164. Roubal K, Myint ZW, Kolesar JM. Erdafitinib: a novel therapy for FGFR-mutated urothelial cancer. Am J Health Syst Pharm. 2020;77:346-51. https://doi.org/10.1093/ajhp/zxz329
165. Abdelgalil AA, Al-Kahtani HM, Al-Jenoobi FI. Erlotinib. Profiles Drug Subst Excip Relat Methodol. 2020;45:93-117. https:// doi.org/10.1016/bs.podrm.2019.10.004

166. Bond DA, Woyach JA. Targeting BTK in CLL: beyond Ibrutinib. Curr Hematol Malig Rep. 2019;14:197-205. https://doi.org/ 10.1007/s11899-019-00512-0

167. Voigtlaender M, Schneider-Merck T, Trepel M. Lapatinib. Recent Results Cancer Res. 2018;211:19-44. https://doi.org/10. 1007/978-3-319-91442-8_2

168. Scott LJ. Larotrectinib: first global approval. Drugs. 2019;79:201-6. https://doi.org/10.1007/s40265-018-1044-x

169. Poratti M, Marzaro G. Third-generation CDK inhibitors: a review on the synthesis and binding modes of Palbociclib, Ribociclib and Abemaciclib. Eur $\mathrm{J}$ Med Chem. 2019;172:143-53. https://doi.org/10.1016/j.ejmech.2019.03.064

170. Miyamoto S, Kakutani S, Sato Y, Hanashi A, Kinoshita Y, Ishikawa A. Drug review: pazopanib. Jpn J Clin Oncol. 2018;48:503-13. https://doi.org/10.1093/jjco/hyy053

171. Hoy SM. Pemigatinib: first approval. Drugs. 2020;80:923-9. https://doi.org/10.1007/s40265-020-01330-y

172. Lamb YN. Pexidartinib: first approval. Drugs. 2019;79:1805-12. https://doi.org/10.1007/s40265-019-01210-0

173. Massaro F, Molica M, Breccia M. Ponatinib: a review of efficacy and safety. Curr Cancer Drug Targets. 2018;18:847-56. https:// doi.org/10.2174/1568009617666171002142659

174. Ajayi S, Becker H, Reinhardt H, Engelhardt M, Zeiser R, von Bubnoff N, et al. Ruxolitinib. Recent Results Cancer Res. 2018;212:119-32. https://doi.org/10.1007/978-3-319-91439-8_6

175. Markham A. Selpercatinib: first approval. Drugs. 2020;80:1119-24. https://doi.org/10.1007/s40265-020-01343-7

176. Markham A, Keam SJ. Selumetinib: first approval. Drugs. 2020;80:931-7. https://doi.org/10.1007/s40265-020-01331-x

177. Berekmeri A, Mahmood F, Wittmann M, Helliwell P. Tofacitinib for the treatment of psoriasis and psoriatic arthritis. Expert Rev Clin Immunol. 2018;14:719-30. https://doi.org/10.1080/ 1744666x.2018.1512404

178. Dhillon S. Trilaciclib: first approval. Drugs. 2021;81:867-74. https://doi.org/10.1007/s40265-021-01508-y

179. Lee A. Tucatinib: first approval. Drugs. 2020;80:1033-8. https:// doi.org/10.1007/s40265-020-01340-w

180. Sathornsumetee S, Rich JN. Vandetanib, a novel multitargeted kinase inhibitor, in cancer therapy. Drugs Today. 2006;42:657-70. https://doi.org/10.1358/dot.2006.42.10.1025318

181. Garbe C, Eigentler TK. Vemurafenib. Recent Results Cancer Res. 2018;211:77-89. https://doi.org/10.1007/978-3-319-91442-8_6 